\title{
Compliance of Goat Farming under Extensive Grazing with the Organic Standards and Its Contribution to Sustainability in Puebla, Mexico
}

\author{
José Nahed Toral ${ }^{1}$, Zenón Gerardo López Tecpoyotl ${ }^{2, *}$, José Roberto Aguilar Jiménez ${ }^{3}$, Daniel Grande Cano ${ }^{4}$ \\ and Claudia Delgadillo Puga ${ }^{5}$ (i)
}

check for updates

Citation: Nahed Toral, J.; López Tecpoyotl, Z.G.; Aguilar Jiménez, J.R.; Grande Cano, D.; Delgadillo Puga, C. Compliance of Goat Farming under Extensive Grazing with the Organic Standards and Its Contribution to Sustainability in Puebla, Mexico. Sustainability 2021, 13, 6293. https:// doi.org/10.3390/su13116293

Academic Editors: Yolanda Mena and Juan Manuel Mancilla-Leytón

Received: 12 March 2021

Accepted: 25 May 2021

Published: 2 June 2021

Publisher's Note: MDPI stays neutral with regard to jurisdictional claims in published maps and institutional affiliations.

Copyright: (c) 2021 by the authors Licensee MDPI, Basel, Switzerland. This article is an open access article distributed under the terms and conditions of the Creative Commons Attribution (CC BY) license (https:// creativecommons.org/licenses/by/ $4.0 /)$.
1 Grupo Agroecología, Departamento de Agricultura, Sociedad y Ambiente, El Colegio de la Frontera Sur., Carretera Panamericana y Periférico Sur S/N, Barrio Ma. Auxiliadora, San Cristóbal de Las Casas, Chiapas 29290, Mexico; jnahed@ecosur.mx

2 Colegio de Postgraduados, Campus Puebla, Boulevard Forjadores de Puebla Núm. 205, Santiago Momoxpan, Municipio de San Pedro Cholula, 72760 Puebla, Mexico

3 Facultad de Medicina Veterinaria y Zootecnia, Universidad Autónoma de Chiapas, Rancho San Francisco Km 8 Carretera Ejido Emiliano Zapata, Tuxtla Gutiérrez, 29060 Chiapas, Mexico; joser.aguilar@unach.mx

4 Área de Sistemas de Producción Agropecuarios, División de Ciencias Biológicas y de la Salud, Universidad Autónoma Metropolitana Iztapalapa, Av. San Rafael Atlixco 186, Col. Vicentina, Alcaldía de Iztapalapa, 09340 Ciudad de México, Mexico; ifig@xanum.uam.mx

5 Departamento de Nutrición Animal Dr. Fernando Pérez-Gil Romo, Instituto Nacional de Ciencias Médicas y Nutrición Salvador Zubirán (INCMNSZ), Vasco de Quiroga 15, 14080 Ciudad de México, Mexico; claudia.delgadillop@incmnsz.mx

* Correspondence: zgerardo@colpos.mx; Tel.: +52-2223246336

Abstract: In order to determine whether organic production may be a viable option for goat farmers of the lower Mixteca region of Puebla, Mexico, in order to increase sustainability of their farms, we evaluated the extent to which these goat farms fulfill organic standards. Additionally, we revised their level of sustainability by calculating an Organic Livestock Conversion Index (OLCI) using 10 indicators and 36 variables. Information was obtained through two means: direct observation and a questionnaire applied to 119 goat farmers of six municipalities of the region. These goat farms principally consist of creole goats that graze in extensive communal rangelands and grasslands in non-arable lands with xerophytic vegetation, and their principal product is meat of adult goats. The goat farms had a moderate level of OLCI (48.0-53.6\%) as well as a moderate level of sustainability $(46.0-58 \%)$ for the goat farms included in this study). Five indicators showed limited compliance of the goat farms, with organic standards. Five showed a high level of compliance. The greater the OLCI value, the greater the sustainability of the goat farms. Increasing the level of compliance of the goat farms of the lower Mixteca region of Puebla, with the organic standards, which would in turn increase their level of sustainability, would require improving technical, social, environmental, and economic aspects of these farms, as well as co-responsibility in promoting sustainable organic goat farming by the different social actors involved (farmers, researchers, technical advisors, and policymakers).

Keywords: extensive livestock farming; organic conversion index; holistic analysis; semi-arid regions; Mixteca Poblana

\section{Introduction}

Livestock production occupies nearly $80 \%$ of global agricultural land [1]. Worldwide, from the year 1500 to 2015, grazing land increased 534\%-from 515 million hectares to 3.24 billion hectares [2], while the forested surface area has been reduced from 5.5 to 4 billion hectares [3]. Latin America and the Caribbean show similar tendencies.

On a global level, there are an estimated 1094 million goats; $52 \%$ of which are in Asia, 42\% in Africa, 3.6\% in the Americas, 1.5\% in Europe, and the remaining 0.9\% in Oceania [4]. Goat production fulfills critical social and economic functions. In arid and 
semi-arid regions of Latin America, small ruminants are the principal source of income for 995,000 families who possess approximately 72.39 million sheep, goats, and South American camelids (llamas and alpacas; [5]).

In Mexico, in 2019 there were 8,790,894 goats on 494,000 goat farms, and goat farming contributed to the economy of approximately 1.5 million Mexicans [6]. Goat production in Mexico, as in the rest of the world, is principally carried out in arid and semi-arid regions, which are covered by xerophytic vegetation and make up approximately $60 \%$ of the country's total surface area. In Mexico, a majority of goats (64\%) are raised in these dry climates in extensive grazing systems with little use of external input, while the remaining $36 \%$ are raised in temperate regions in extensive and intensive systems. As mentioned above, goat extensive production is mostly carried out on natural semiarid rangeland $[7,8]$. These are non-arable lands due to low and erratic rainfall, rugged topography, poor drainage, or cold temperatures. In many parts of the world grazing systems are characterized by true collaboration with nature rather than control over nature. As one of the most prevalent terrestrial systems on the planet, natural semi-arid rangeland is a critical habitat for a great variety of species of plants and animals and is part of many of the world's watersheds. On these natural lands, the herdsmen feed native and domestic animals [9]. In an unpredictable, vulnerable, and dynamic environment, such as that prevailing in rangelands, herdsmen have developed successful adaptation mechanisms to maintain an ecological balance between their practice and the natural environment. Therefore, this form of management represents a well-adapted economic and social system, mainly to dryland conditions, characterized by a complex set of practices that derives from knowledge that has allowed the maintenance of a sustainable balance between pastures, livestock systems and people [10].

Organic livestock production has been proposed as an alternative to conventional livestock farming [11] in that it promotes health, equity, precaution, responsibility, ethics, agroecology, and sustainability [12]. Organic livestock production is carried out using pastoral, silvopastoral, and agrosilvopastoral practices, closing the soil-plant-animal cycle, conserving the environment and its biodiversity, promoting animal welfare, avoiding agrochemical use, and providing consumers with animal products with high organoleptic, nutritional, and hygienic-sanitary quality [12]. Furthermore, it forms part of the paradigm of agroecology, as a movement of resistance to dependence on external input such as industrial feed and agrochemicals, machinery and fossil fuel, as promoted by the Green Revolution agricultural model [13-15]. It follows the principles of sustainability, aiming to simultaneously fulfill economic, social, cultural, and environmental objectives $[16,17]$.

The evaluation of the production possibility conversion of conventional livestock production to organics is of great interest $[16,18,19]$. The evaluation of the possibilities of converting conventional livestock production to organics should follow a dynamic multidisciplinary systems approach and include technical, social, environmental, and economic criteria $[20,21]$. For this, no universal parameters exist, and appropriate tools and methodologies are still being developed [18,22-25]. For such evaluations to be operative, it is necessary to characterize the behavior of the relevant indicators, integrate variables, be sensitive to the contexts of a wide range of livestock systems and identify trends of change in the productive systems evaluated. Moreover, indicators should be easily and reliably measurable as well as easy to understand $[17,26]$. Aside from evaluating conversion of conventional livestock production to organics, certification of foods of animal origin from grazing systems, according to international organic standards (i.e., IFOAM norms), allows for these products to be competitive in terms of quality when compared with conventional products [27]. Nevertheless, lack of quality control of meat, milk, and cheese produced in Mexico makes it impossible to market these products in organic or agroecological niche markets and results in relatively low prices.

Along with evaluation and promotion of organic livestock farming and animal production systems based on grazing, the application of sustainability principles to livestock production are of great interest. Many studies [28-30] have highlighted the contribution 
of organic production to increasing the level of sustainability of livestock systems. Researchers, policymakers, and farmers have become increasingly interested in applying principles of sustainability to goat farming, as well as in evaluating the sustainability of goat production systems [31-36].

The objectives of this study were to evaluate the extent to which conventional goat farms of the lower Mixteca region of Puebla, Mexico, comply with the organic standards; to identify their limiting factors, potential, and opportunities for organic conversion; as well as to determine whether organic production may be a viable option for increasing the social, environmental, and economic sustainability of the farms.

\section{Conceptual Aspects Related to the Research Topic}

Conceptually, conventional animal production is based on extensive management and is characterized by being part of an ecosystem modified to a greater or lesser extent by human beings. It is practiced in extensive areas of land for grazing with low external input use, and low production costs. In general, weight gain and milk production are lower than those obtained in intensive systems [37].

On the other hand, an animal production system is sustainable if it can reproduce itself for a reasonable time and can change in due course when conditions require it to continue functioning in the long term. For this, the ecological and social resources and processes that make it work must be able to reproduce and thus self-regulate, coordinate to be compatible, cushion circumstantial disturbance promptly, reorganize and adapt to internal and external structural changes. This general definition: (1) makes it possible to identify the trends of change prevailing in production systems and their possible consequences, and (2) helps to define desirable scenarios and to identify one or more planned interventions on the system that may modify its current undesirable trends [24,25].

Livestock production units are considered small, medium, or large enterprises that must be socially responsible in order to contribute to achieving the goal of raising awareness of social and environmental global problems [38]. Sustainability includes three aspects, criteria, dimensions or characteristics (environmental, social, and economic) [39,40]. An underlying assumption, and possible consequence of this process, is that a livestock enterprise can only survive in the long term if it proves to be economically viable, environmentally sustainable, and socially responsible. These three aspects also constitute the conceptual framework of the so-called Triple Bottom Line (TBL) concept of sustainability, proposed by Elkington in 1997 [41].

In addition to the considerations previously mentioned on organic livestock production, other fundamental aspects that can be highlighted are reviewing and respecting the list of substances allowed, prohibited and restricted by organic regulations. The establishment of management and promotion mechanisms for organic livestock is recommended. To minimize the residual effect of previously used agrochemicals, a necessary transition or conversion period ( $2-4$ years) is also required. It is necessary to train farmers in the substitution of polluting technologies, dependent on monetary investments that degrade the physical environment, for others with less demand for money and based on the efficient use of local resources; these technologies allow the maintenance of the biodiversity and the long-term productive capacity of the soil. The certification of foods of animal origin from agrosilvopastoral systems subject to organic regulations offers better options in the new dynamics of the market and allows them to compete for quality with foods produced in a conventional way [12].

\section{Materials and Methods}

\subsection{Location of the Study Area and Its Environmental and Socioeconomic Context}

The present study was carried out in six municipalities of the lower Mixteca region of Puebla: Acatlán (A), San Pedro Yeloixtlahuaca (from here on called San Pedro or SP), Guadalupe $(\mathrm{G})$, Tehuitzingo (T), Chinantla (C), and Piaxtla (P); (Figure 1). The region is located between $18^{\circ} 05^{\prime} 36^{\prime \prime}$ and $18^{\circ} 21^{\prime} 30^{\prime \prime}$ north latitude and $17^{\circ} 59^{\prime} 12^{\prime \prime}$ and $18^{\circ} 21^{\prime} 31^{\prime \prime}$ west 
longitude. The Mexican Mixteca covers an area of $34,869 \mathrm{~km}^{2}$, which includes parts of the Guerrero, Oaxaca, and Puebla states in the south of the country. The Mixteca Poblana has an area of $11,025 \mathrm{~km}^{2}$, which represents $32.5 \%$ of the total area of the Puebla state [42].

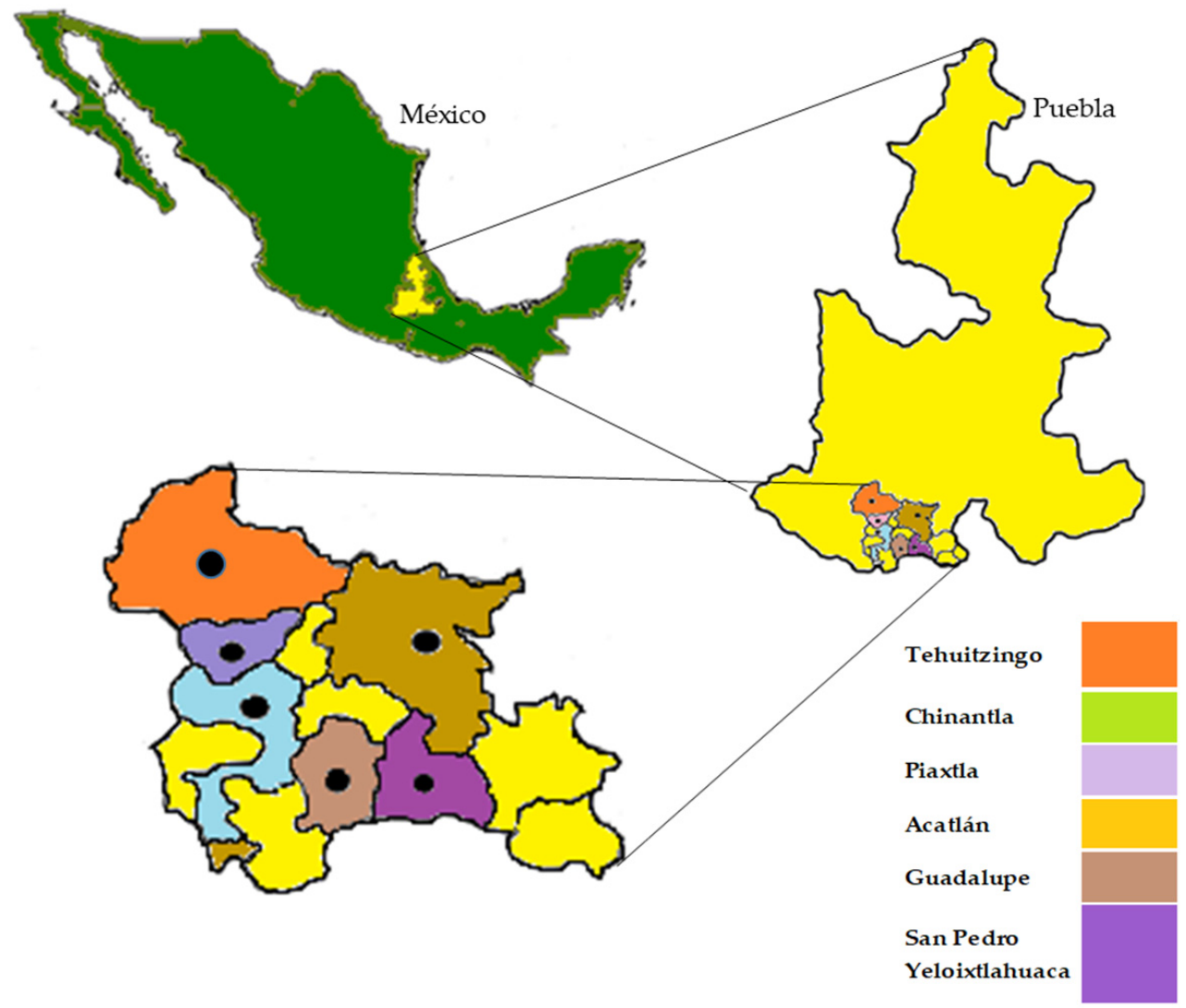

Figure 1. Location of the municipalities studied in the lower Mixteca region of Puebla, Mexico.

The lower Mixteca region of Puebla covers an area of $2603 \mathrm{~km}^{2}$; the six municipalities in which the study was carried out occupy an area of $1741 \mathrm{~km}^{2}$ [43], representing $15.8 \%$ of the total area of the Mixteca Poblana. The main types of climate are warm and humid with summer rainfall (range $51-99 \%$ in six municipalities) to very warm, and warm semi-dry (range $18-94 \%$ in six municipalities) [44]. The rainy season is from May to September. Precipitation fluctuates in the range between $600-900 \mathrm{~mm}$ and temperature between 18 and $26{ }^{\circ} \mathrm{C}$ [45].

Dominant soils are Leptosols, Regosols, Fluvisols, Phaeozem, and, in a very small proportion Kastanozems [44]. Soils are thin and have suffered a high level of aeolian as well as hydric erosion. The predominant vegetation is low deciduous forest, in some areas associated with secondary shrub or tree vegetation, as well as oak forest and small extensions of induced grassland [46]. In the six municipalities, the predominant vegetation is the low deciduous forest, sometimes associated with secondary shrub or tree vegetation; farmers in the region point out that the most important tree and shrub species for feeding goats are: Acacia cochliacantha (Cubata negra), Acacia farnesiana (Huizache), Lysiloma tergemina (Pata de cabra), Senna wislizeni (Rompebotas), Acacia bilimekii Macbride (Tehuixtle), Mimosa lacerata (Uña de gato), Pithocellobium acatlense Bentn (Barba de Chivo), Acacia picachensis (Cierrecillo), Eysenhardtia polystachya (Cuatillo), Acacia macilenta (Huizpantle negro), Acacia berlandieri (Huizpantle blanco), and Acacia pennatula (Cubata blanca).

According to the localities size in the municipalities studied, in 2010 all municipalities were classified as rural, except Acatlán, which was considered as mixed [43]. To a great extent of the Mixteca Poblana, quality of life indexes are very low, with limited opportunities for employment, education, health, housing, food, a liveable wage, access to sports 
and culture, which in some municipalities causes the migration of young people to the United States of America [42]. Of the six municipalities studied, in 2010 San Pedro had the lowest population density $\left(19.4\right.$ inhabitants $\left./ \mathrm{km}^{2}\right)$, while the municipality of Acatlán had the highest population density (55.6 inhabitants $/ \mathrm{km}^{2}$ ) [43].

The illiteracy rates in 2010 ranged from 11.9 to $23.9 \%$, with the lowest in Acatlán and the highest in Guadalupe; with an average level of schooling of 7.6 and 5.0 years, respectively. For the same year, the average schooling in all municipalities was 6.1 years [44]. Based on 2010 data, it was recorded that in the six municipalities the main building materials in the houses were cement floors (73.7-88.7\%), concrete roofs (61-83.7\%), and brick walls (75.5-90.4\%). On the other hand, the availability of drinking water, drainage, and electricity were very contrasting. In Tehuitzingo, only $30.3 \%$ of households had such services, while in Chinantla the availability was 71.1\% [43]. In 2000, in Chinantla, Guadalupe, Piaxtla, and Tehuitzingo, the main type of work was self-employment (29-44\% of the total population), while in Acatlán and San Pedro people were employed as manual workers ( $42.4 \%$ and $29.5 \%$ of the employed population, respectively).

In 2010, the economically active population in all municipalities was predominantly male (64.1-77.8\%). At the municipal level, in the year 2000, the percentage of the population engaged in primary activities (agriculture, livestock farming) was only $2.5 \%$ [43]. However, in several of the municipalities studied, goat farming is the main economic activity. Some of these were selected for this study. In 2010 in the six municipalities, the percentage of the population without health services was $37-55.4 \%$, with the lowest percentage in Chinantla and the highest in Piaxtla [43]. Based on the above, and with data from 2015, it was considered that with the exception of the municipality of Acatlán, which had a medium degree of marginalization, the rest of the municipalities studied presented a high degree of marginalization [43].

\subsection{Methodology}

This section addresses four topics: (I) sample selection and sample frame; (II) level of compliance of the conventional goat farms with organic standards; (III) goat production and sustainability, and (IV) information analysis.

\subsubsection{Sample Selection and Sample Frame}

The lower Mixteca region of Puebla comprises 12 municipalities: Acatlán, Ahuehuetitla, Axutla, Cuayuca de Andrade, Chinantla, Guadalupe, Petlalcingo, Piaxtla, San Jerónimo Xayacatlán, San Pablo Anicano, San Pedro Yeloixtlahuaca, Tehuitzingo, and Xayacatlán de Bravo. They are located in the southeast of the state of Puebla, Mexico, where goat livestock production is one of the main activities carried out. In this region, there are 3971 production units dedicated to goat raising, with a population of 68,442 heads [47]. Because it is a large region with rugged terrain, the study was conducted in six randomly selected municipalities. The sample size of the goat production units studied was calculated using the simple random sampling method, using the equation proposed by Méndez et al. [48]:

$$
n=\frac{1.96^{2}\left(\sigma^{2}\right)}{\delta^{2}}
$$

where: $n$ is the sample size; $(1.96)^{2}$ is a constant value; $\sigma^{2}$ is the variance of the number of goat production units in the six municipalities (129.4) and $\delta^{2}$ is the accepted limit of error $(25 \%)$. According to the above, 103 goat farms were considered in the study. However, due to the knowledge of the area and the farmers, a total of 119 goat farms were finally studied.

Due to the fact that in the region, there does not a census of goat farmers, technicians from two rural development agencies working with farmer groups helped to obtain the information. It was obtained through direct field observations and semi-structured interviews $[49,50]$, using a previously prepared questionnaire. Then, data was recorded on Excel sheets for further analysis and interpretation. 
Our research team relies on the informed consent of goat farmers and municipal and community authorities expressed openly through meetings, training courses, and advice that we have offered over more than 18 years of working with them. During this time, a relationship of trust has been established with farmers given that we work directly with them. Our research team has a strong commitment and respect for the goat farmers' work in the region, which has been reflected in the support given to farmers for the construction of infrastructure for the harvesting and storage of rainwater or technological innovations for the cultivation of sorghum [51,52].

Goats farmers have also offered direct actions as instruction for the collection, drying, and sending of vegetative material used in the research studies that have been carried out [53-55], and others that are currently underway, with the aim of isolate, characterize and evaluate bioactive compounds with antioxidant, antimicrobial, antiinflammatory, antiobesity, and antidiabetic activity of the Acacia farnesiana fruits.

The fruits or pods of trees and shrubs are one of the main forage resources present in the natural semi-arid rangeland of the lower Mixteca region of Puebla. Ranchers depend on them to supplement the feeding of goats in pasture, depending almost exclusively on the fruits or pods of this resources during the dry season.

Our research team has been deeply respectful of farmers; we value the commitment of the farmer and his roots to the land. Therefore, the focus of our research and discussion was carried out in a holistic way, considering the technical, social, environmental, and economic aspects of goat production.

\subsubsection{Level of Compliance of Conventional Goat Farms' with Organic Standards}

We evaluated the level of compliance of the goat farms with the organic standards using the Organic Livestock Conversion Index (OLCI), proposed by Nahed et al. [16] and Mena et al. [18], adapted to the conditions of goat farming in the lower Mixteca region of Puebla, considering that the organic production model could be a viable alternative for increasing their sustainability. OLCI is an index that takes into account technical, social, environmental, and economic criteria and consists of 10 indicators and 36 variables (Table 1); involving aggregation and weighting of information [56-58]. This index (I) allows for understanding limitations, potentials, and opportunities of goat farms in a particular economic and social context, and (II) contributes to decision making to facilitate farms transitioning toward organic production. The methodology is based on the principles of the organic production model with respect to (I) use of permitted, prohibited, and restricted substances for preventing, treating and eradicating pests and diseases, (II) agroecological technologies which do not depend on capital and do not contaminate, and which are based on efficient use of local resources in order to maintain biodiversity and long-range soil productivity [59]; and (III) implementation of mechanisms for managing and promoting ecological livestock farming.

Variables were codified as binomial $(0,1)$ in order to homogenize the original units of measure and facilitate calculating the real value of each indicator (without weighting)-that is, the arithmetic average of the 0 or 1 responses [60]. The optimal value $(100 \%)$ of an indicator without weighting is achieved when the responses of all of its variables are positive (codified as 1). The ten indicators were standardized to a relative percentage scale (\%). The percent value of each indicator was calculated by averaging the responses of their variables ( 0 or 1 ) and multiplying this figure by 100 . The weighting coefficient or specific weight of each indicator for the study region was defined by 12 experts in organic livestock production based on: (I) the importance of the indicator to the principles of agroecology and organic livestock production, and (II) the difficulty of eliminating or substituting input or practices related to that indicator which are prohibited by organic standards. The weighted value of each indicator was obtained by multiplying its value by its specific weighting factor, and the OLCI value of each goat farm was obtained by summing the weighted values of the 10 indicators. 
Table 1. Indicators, weighting factors, and variables for calculating the Organic Livestock Conversion Index for goat production in the lower Mixteca region of Puebla, Mexico.

\section{(1) Feed Management (0.12):}

1.1. Animals are fed only with feed permitted by organic standards

1.2. Farmers allow their goats to graze

1.3. At least $60 \%$ of the daily ration is common fodder

1.4. At least $50 \%$ of feed comes from the same farm or another ecological farm

(2) Sustainable rangeland management (0.15):

2.1. Rotation of grazing land

2.2. Appropriate stocking rate

2.3. Association of fodder crops

2.4. Cultivation of woody fodder crops (shrubs and/or trees)

2.5. Management of agrosilvopastoral systems

2.6. Improvement of natural grasses

(3) Soil fertilization (0.06):

3.1. Chemical

3.2. Organic

(4) Weed control in rangelands and grasslands (0.06):

4.1. Chemical

4.2. Ecological

(5) Pest and disease control in rangelands and grasslands (0.06):

5.1. Chemical

5.2. Ecological

(6) Disease prevention and veterinary care (0.12):

6.1. Farmers apply vaccines only against endemic diseases

6.2. Farmers quarantine introduced and/or sick animals

6.3 Farmers use natural treatments (e.g., herbalism, homeopathy, acupuncture, or nothing)
6.4. Internal and external deworming is carried out through natural methods (e.g., herbalism, homeopathy, acupuncture, or nothing) or permitted allopathic anti-parasitic medicine

(7) Breeds and reproduction (0.06):

7.1. Proportion of creole goats

7.2. Natural reproduction of animal

(8) Animal welfare (0.07):

8.1. Suckling until 45 days

8.2. Sufficient space per animal in roofed facilities and outdoors

8.3. Sufficient feeders and troughs

8.4. Protection from inclement weather (cold, heat, rain, humidity)

8.5. Horns of animals under six months of age are cut, or those of any age trimmed.

(9) Food safety (0.15):

9.1. Strict hygienic-sanitary control of installations and equipment

9.2. Animals have been demonstrated to be free of (I) Brucellosis and (II) Tuberculosis

9.3. Animals seropositive to (I) Brucellosis and (II) Tuberculosis are sacrificed

9.4. Products have been demonstrated to be free of (I) antibiotics, (II) hormones, and (III) pesticides

(10) Ecological management (0.15):

10.1. Farmer receives advisory and/or training for organic certification

10.2. Farmer has an organic development plan or is certified

10.3. Farmer records steps to comply with organic standards

10.4. Farmer receives incentives for organic livestock production based on quality

10.5. Farmer receives fair prices for products

\subsubsection{Goat Production and Sustainability}

This section addresses a holistic, social, environmental, and economic analysis of goat production sustainability in the lower Mixteca region of Puebla using some qualitative and quantitative indicators previously defined by Toussaint [61], Mena et al. [62], and Nahed et al. [24]. Specific sustainability data were taken from Nahed and López ([63], Table 2). These authors used the framework for the assessment of natural resource management systems incorporating sustainability indicators [63] for their estimation.

Table 2. Average values (\%) of the five sustainability attributes considered to obtain the average value of the Sustainability Index in six municipalities of the Mixteca region of Puebla, Mexico.

\begin{tabular}{|c|c|c|c|c|c|c|}
\hline & \multicolumn{6}{|c|}{ Municipalities } \\
\hline & Guadalupe & Acatlán & San Pedro & Chinantla & Tehuitzingo & Piaxtla \\
\hline $\begin{array}{l}\text { Sustainability } \\
\text { Attributes }\end{array}$ & (G) $n=20$ & (A) $n=20$ & (SP) $n=20$ & (C) $n=20$ & (T) $n=19$ & (P) $n=20$ \\
\hline 1. Productivity, $\%$ & 60.7 & 54.3 & 58.9 & 53.3 & 54.8 & 63.6 \\
\hline $\begin{array}{l}\text { 2. Stability, reliability, } \\
\text { resilience, } \%\end{array}$ & 53.2 & 50.2 & 51.0 & 53.2 & 51.8 & 50.1 \\
\hline 3. Adaptability, $\%$ & 37.4 & 33.5 & 46.1 & 30.5 & 32.1 & 46.8 \\
\hline 4. Equity, \% & 49.8 & 56 & 50.6 & 53.9 & 54.1 & 50.6 \\
\hline 5. Self-management, $\%$ & 36.5 & 34.4 & 30.9 & 55.9 & 58.7 & 80.9 \\
\hline Sustainability index, \% & 48.0 & 46.0 & 48.0 & 49.3 & 50.3 & 58.4 \\
\hline
\end{tabular}

Source: Nahed and López [63]. 


\subsubsection{Information Analysis}

Information was systematized by grouping the goat farms according to the municipality to which they belong. Once normality of the data distribution was verified [61], average values of the social, environmental, and economic variables-as well as of OLCIwere examined using one-way analysis of variance to detect possible differences among groups of goat farms by the effect of the municipalities. The ANOVA test with a Welch correction was applied to those variables whose variances among groups were not homogenous (determined through the Levene test of homogeneity of variances). In order to determine statistical differences among groups, variables showing significant differences in the ANOVA test were submitted to a posteriori contrasts (multiple comparisons) using (I) Tukey's HSD method for variables showing homogenous variances and (II) the Games-Howell test for variables with unequal variances [60].

Regression analysis [64] allowed for determining: (I) the cause-effect relationship between social, environmental, and economic variables and economic net margin per ha of grazing land per year; (II) the relationship between the values of the ten OLCI indicators and the values of the sustainability index reported by Nahed and López [63] for the goat farms of the present study (Table 2); (III) the relationship between net margin per ha of grazing land per year and the values of the sustainability index, and (IV) the relationship between the OLCI values and those of the sustainability index. Statistical data analyses were carried out using the Statistical Package for Social Sciences program, version 15.0 [65].

\section{Results and Discussion}

\subsection{General Characteristics of Conventional Goat Production of the Lower Mixteca Region of Puebla, Mexico}

Historically, in the region of study goats are predominantly raised by farm families who grow crops and raise animals according to traditional agrosilvopastoral management principally for self-consumption with local sale of excess products. The principal objective of all goat farms is production of kids. Males are fattened after weaning, for family consumption, or to be sold within the region as breeding males or to be slaughtered for meat. Females remain in the herd to replace older goats, which are sold as discarded adults. The principal product of the goat farms is meat of adult animals. Aside from cultivating small areas of seasonal crops, the goat farmers also raise other domestic animal species (e.g., pigs, chickens, turkeys), though to a lesser extent than goats.

Goat raising in the lower Mixteca region of Puebla is extensive, principally using creole goats, which are adapted to local climatic and management conditions and therefore resist long periods of grazing. During the extremely dry season, goats feed on the bark of trees and shrubs [66]. The basis of their diet is rangelands, with a low level of seasonal fodder supplementation $[67,68]$. They graze 6 to $10 \mathrm{~h}$ daily, covering 8 to $15 \mathrm{~km}$, browsing the native vegetation of communal rangelands. Rotation among grazing sites varies from one day to 6 months. Diet varies with the season, and as a consequence, the animals lose $30 \%$ of their live weight during the dry season. Goat reproduction is seasonal, and goats are polyestrous. Respiratory problems and parasites are common, as is the mortality of kids during the dry season. Men, women, children, and elders participate in caring for the goats [66].

The goat farms of the lower Mixteca region of Puebla have a low level of infrastructure, equipment, and technological development. Few of the goat farms have access roads in good conditions, running water, and electricity, which greatly limits the implementation of innovations in these goat farms $[69,70]$. Furthermore, farmers use few external inputs, have a low level of economic reinvestment, use resources in a holistic manner, and have a management calendar adapted to the high level of variability of environmental conditions, similar to other livestock systems $[16,71,72]$. The fact that goat farmers do not form farmers' organizations, it limits marketing channels, and this in turn affects product prices [67]. Global and local technological, social, economic, environmental, and political changes may pose opportunities (e.g., niche markets, payment for environmental services) and/or 
threats (e.g., climate change, lack of generational turnover, dependence on purchased inputs) for the goat farmers' livelihoods.

\subsection{Level of Compliance of Conventional Goat Farms' with Organic Standards}

Evaluating the level of compliance of goat farms with organic standards allows for identifying their limits, potentials, and opportunities for transitioning toward organic farming $[19,59]$. The OLCI values of the goat farms in the six evaluated municipalities $(48.0-53.6 \%)$ were the result of the low values in the indicators sustainable rangeland management (with the exception of Piaxtla); organic soil fertilization, disease prevention, veterinary care, food safety, and ecological management. Meanwhile, the indicators of feed management, weed control in rangelands and grasslands, ecological control of pests and diseases in rangelands and grasslands, breeds and reproduction, and animal welfare were highly approximate to organic management (Table 3). Goat farms of the municipality of Piaxtla showed statistically greater OLCI values $(53.6 \%)$ than those of the remaining municipalities, which had similarly lower values (48.0-49.2\%).

The OLCI values of the goat farms evaluated in the six municipalities (48.0-53.6\%) are lower than those obtained for the agrosilvopastoral systems of dairy cattle in southeastern Mexico (62.5-64.6\%, Nahed et al. [16]) and on dairy goat farms in mountainous areas of Andalusia, Spain (55-81\%, Mena et al. [73]), but similar to those of dairy goat farms in the Northern Sierra of Seville (38.7-58.6\%, Mena et al., [18]), as well as those of conventional cattle production in the dry tropics of Chiapas, Mexico (48.0\%, Aguilar-Jiménez et al. [74]) and the agrosilvopastoral systems in Marqués de Comillas, Chiapas (53.3\%, Nahed et al. [75]). However, they are greater than those obtained for beef cattle grazing in pastures with scattered trees in Spain (35.9-46.2\%, Escribano [76]). Below, we present each of the indicators that integrate OLCI.

\subsubsection{Feed Management}

All the goat farms of the six municipalities showed a high (92.1-100\%) approximation level to the organic standards for this indicator (Table 3). This is largely due to the fact that goats are fed almost exclusively through grazing in rangelands, with which they fulfill the requisite that at least $60 \%$ of dry matter $(\mathrm{DM})$ of the daily ration come from common green (grazed or cut), tedded, or silage fodder, and that at least $50 \%$ of feed come from the same farm or another organic farm. In the study region, the incorporation of common fodder includes making use of fruit and pods of local shrubs and trees, which are largely collected directly by the animals during grazing [77]. External supplements are not used in three municipalities $(\mathrm{G}, \mathrm{A}$, and $\mathrm{SP}=0.0 \%)$. Some goat farms of the other three municipalities use external supplements sporadically $(\mathrm{C}=5.0 \% ; \mathrm{T}=32.0 \% ; \mathrm{P}=5.0 \%)$, and provide the animals with commercial mineral salt and some non-organic feed, such as sorghum grain and corn grain and stover [78]. As a result, these goat farms did not fully comply with the organic standard that animals graze at least six hours per day, particularly in the municipality of Tehuitzingo, which has a $68 \%$ level of compliance with the organic standards for this variable, followed by Chinantla and Piaxtla, which have a 95\% level of compliance.

In the six municipalities that were evaluated the aspects of goat feeding mostly fulfill organic standards. It is based on grazing that does not use prohibited feed such as animal excrement as well as the fact that it uses less commercial products or chemical additives [79-81]. However, mineral salt should be substituted with another permitted type of salt in the organic standards and purchased grains and fodder should be obtained from organic farms. 


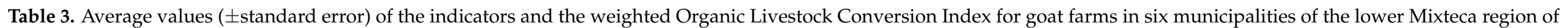
Puebla, Mexico.

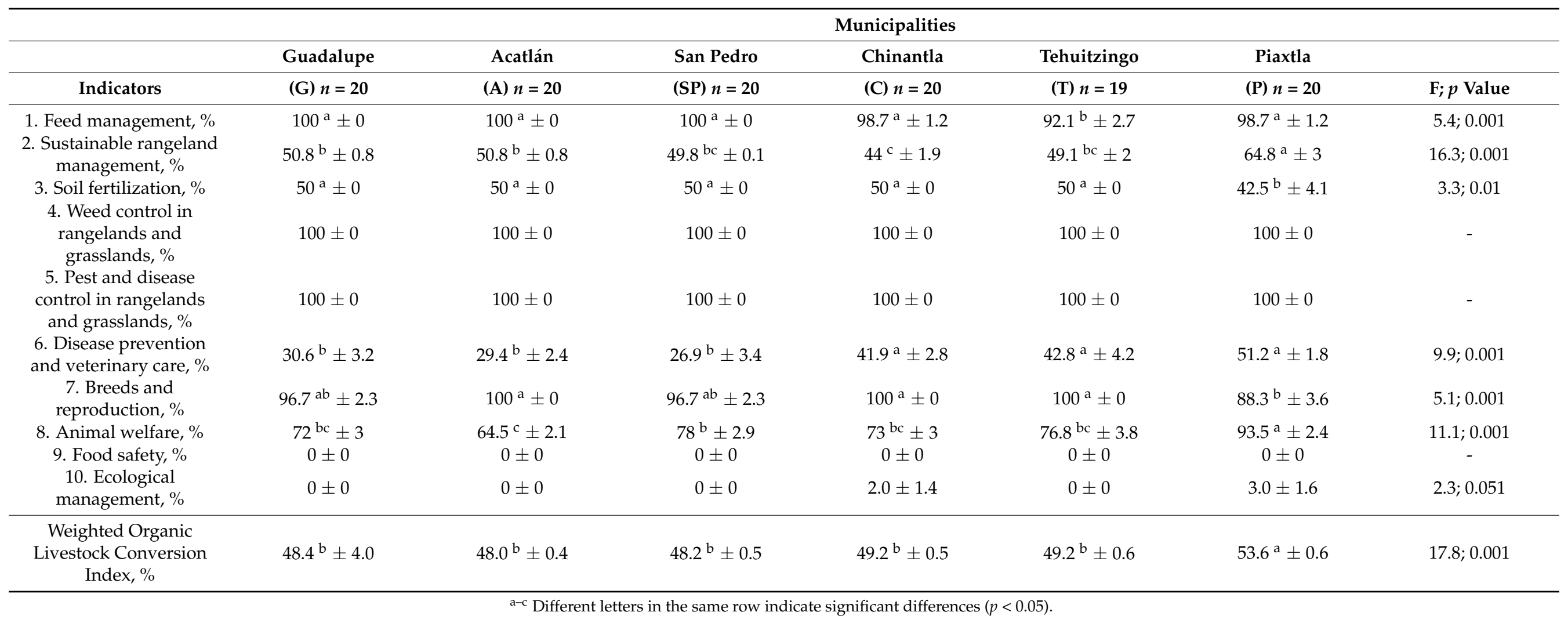




\subsubsection{Sustainable Rangeland Management}

Based on the values obtained for this indicator, the goat farms of the municipalities of Guadalupe, Acatlán, San Pedro, and Tehuitzingo showed an intermediate level of compliance with the organic standards (approximately 50\%), while the goat farms of Piaxtla had the highest level of compliance $(64.8 \%)$. The goat farms of Chinantla showed a low $(44.0 \%)$ level of compliance with the organic standards (Table 3 ) due to low levels in several aspects of rangeland management: (I) rotation of grazing sites $(\mathrm{G}=5.0 \% ; \mathrm{A}=0.0 \%$; $\mathrm{SP}=0.0 \% ; \mathrm{C}=0.0 \% ; \mathrm{T}=0.0 \% ; \mathrm{P}=60.0 \%)$, (II) cultivation of woody fodder crops $(\mathrm{G}=0.0 \%$; $\mathrm{A}=0.0 \% ; \mathrm{SP}=0.0 \% ; \mathrm{C}=0.0 \% ; \mathrm{T}=5.0 \% ; \mathrm{P}=0.0 \%$ ), and (III) improvement of natural grasses $(\mathrm{G}=0.0 \% ; \mathrm{A}=5.0 \% ; \mathrm{SP}=0.0 \% ; \mathrm{C}=0.0 \% ; \mathrm{T}=5.0 \% ; \mathrm{P}=30.0 \%)$. However, levels of other aspects of rangeland management were considerably high: (I) appropriate stocking rate (0.38 to $0.76 \mathrm{UA} \mathrm{ha}^{-1} ; \mathrm{G}=100 \% ; \mathrm{A}=100 \% ; \mathrm{SP}=99.0 \% ; \mathrm{C}=99.0 \% ; \mathrm{T}=100 \% ; \mathrm{P}=99.0 \%$ ), (II) association of fodder crops (100\% in all six municipalities), and (III) management of silvopastoral systems ( $\mathrm{G}=100 \% ; \mathrm{A}=10 \%$; $\mathrm{SP}=100 \% ; \mathrm{C}=65.0 \% ; \mathrm{T}=84.0 \% ; \mathrm{P}=100 \%$ )

In order to achieve rangeland sustainable management, it is necessary to promote planting in different agronomic arrangements of woody local fodder plants such as: Acacia cochliacantha (Cubata), Acacia farnesiana (Huizache), Lysiloma tergeminum (Pata de cabra), Senna wislizeni (Rompebota), Acacia bilimekii (Tehuixtle), Mimosa lacerata (Cat's claw), Pithecellobium acatlense Benth (Barba de chivo), Prosopis laevigata (Mezquite), Haemotoxylum brasiletto (Brazilwood), and Pithecellobium dulce (Manila tamarind), which are widely distributed in the Mixteca region and are consumed by goats [82-85].

With respect to goat consumption preferences during grazing-browsing, some benefits of the pods of Acacia farnesiana have been documented. They are not only important fodder resources, but also provide bioactive compounds such as antioxidants, anti-inflammatory compounds, and anti-microbial that have been shown to regulate certain physiological processes [86-88]. Rangelands with woody species provide greater soil protection, biodiversity, and environmental services such as $\mathrm{CO}_{2}$ sequestration, and contribute to the reduction in $\mathrm{CH}_{4}$ emissions as well as mitigation of climate change [13,81].

\subsubsection{Soil Fertilization}

With respect to the indicator soil fertilization, all evaluated goat farms of the municipalities show an intermediate level of compliance with organic standards (50\%), with the exception of the goat farms of Piaxtla, which show a lesser (42.5\%) level of compliance (Table 3). The values obtained for this indicator are a result of the fact that in all municipalities, most goat farmers (G, A, SP, and $\mathrm{C}=100 \% ; \mathrm{P}=85.0 \%$ ) do not use chemical fertilizers in their rangelands, but rather, they are fertilized only with manure dropped by the goats during grazing. However, intermediate levels of this indicator are found due to the fact that none of the farmers of the goat farms evaluated process goat manure accumulated in the corrals into organic fertilizer (e.g., bocashi, worm compost, or other types of compost, beneficial micro-organisms, or liquid biofertilizers), nor do they use green manure or cover crops to fertilize rangelands and grasslands, as suggested by Lague et al. [89], Labrador and Porcuna [90], and Nogueroles and Sicilia [91].

\subsubsection{Weed Control in Rangelands and Grasslands}

The goat farms of all six municipalities have a very high level of compliance $(100 \%)$ with the organic standards for weed control in rangelands and grasslands (Table 3). Due to the fact that no farmers use synthetic herbicides; but rather weed control is carried out manually, and therefore they fulfill this indicator at a level of $100 \%$. Ecological weed control involves maintaining weed populations in rangelands and grasslands at acceptable levels, without completely eradicating them [92].

\subsubsection{Pest and Disease Control in Rangelands and Grasslands}

With respect to ecological pest and disease control in rangelands and grasslands, the goat farms of all six municipalities have very high levels of compliance with organic 
standards (100\%, Table 3) stemming from the fact that the farmers do not use chemical pesticides to control grasshoppers (Gryllus spp.), leafhoppers or chicharritas (Dalbulus spp., Cicadulina spp.,), or other pests in grasslands. Rather, their principal methods of control are manual and mechanical (through grazing). The use of botanical insecticides and repellents [93] and integrated pest management, which includes ecological control of soil and biodiversity [94], could improve the efficiency of pest and disease control [79].

\subsubsection{Disease Prevention and Veterinary Care}

With respect to disease prevention and veterinary care indicator, the goat farms of almost all the municipalities showed a low level of compliance with organic standards, with the exception of Piaxtla, which has an intermediate level of compliance (Table 3). This is due to the fact that the goat farms do not adequately comply with organic standards regarding, for example: (I) vaccination against endemic diseases such as Brucellosis, Derriengue (bovine rabies), Clostridiasis, and Pasteurellosis $(\mathrm{G}=10.0 \% ; \mathrm{A}=0.0 \% ; \mathrm{SP}=17.5 \%$; $\mathrm{C}=40.0 \% ; \mathrm{T}=50.0 \% ; \mathrm{P}=67.5 \%)$, (II) quarantining for introduced or sick animals $(0.0 \%$ in all municipalities), (III) use of natural treatments ( $\mathrm{G}=50.0 \% ; \mathrm{A}=20.0 \% ; \mathrm{SP}=35.0 \%$; $\mathrm{C}=50.0 \% ; \mathrm{T}=58.0 \% ; \mathrm{P}=90.0 \%)$, and $(\mathrm{IV})$ parasite control $(\mathrm{G}=63.0 \% ; \mathrm{A}=98.0 \% ; \mathrm{SP}=55.0 \%$; $\mathrm{C}=78.0 \% ; \mathrm{T}=63.0 \% ; \mathrm{P}=48.0 \%)$. Common diseases in the region are mange, lice, pneumonia, interdigital dermatitis (foot root), and diarrhea. Some goat farmers do not apply internal anti-parasite medicines and some carry out more than the two permitted by the organic standards per year. Sustainable control of endoparasites involves prevention through grazing management, as well as the use of plant extracts, homeopathic treatments, fodders containing components such as polyphenolic proanthocyanidins, and biological parasite control (for example releasing native or exotic enemies of harmful nematodes in grasslands), as well as breeding to develop genetic resistance to infestations of nematodes [28]. The majority of goat farmers sporadically use antibiotics to treat infections. The level of this indicator could be improved by carrying out preventive measures to favor resistance to diseases -including nutritional management, promoting animal welfare, raising creole breeds and their crosses, and substituting antibiotics and anti-parasite medicines with natural methods such as homeopathy, herbalism, and acupuncture $[79,80]$.

\subsubsection{Breeds and Reproduction}

For this indicator, the goat farms of five municipalities have very high levels of compliance with organic standards (>90\%, Table 3), while Piaxtla stands out with a high level (88.3\%). The five municipalities with very high levels fulfill 96.7 to $100 \%$ of the organic standards, given that at least $75 \%$ of the goats are Creole and/or other breeds adapted to the region. Moderate levels of adaptation of the animals to local climatic and management conditions is reflected in intermediate birth rates $(\mathrm{G}=60.0 \% ; \mathrm{A}=74.0 \% ; \mathrm{SP}=74.2 \%$; $\mathrm{C}=53.0 \% ; \mathrm{T}=47.9 \% ; \mathrm{P}=87.0 \%)$ and intermediate death rates of kids $(\mathrm{G}=18.0 \%$; $\mathrm{A}=22.8 \% ; \mathrm{SP}=14.5 \% ; \mathrm{C}=8.9 \% ; \mathrm{T}=3.2 \% ; \mathrm{P}=16.2 \%$ ), while the adult goat death rate is low $(\mathrm{G}=4.5 \% ; \mathrm{A}=7.9 \% ; \mathrm{SP}=3.2 \% ; \mathrm{C}=1.0 \% ; \mathrm{T}=1.7 \% ; \mathrm{P}=5.1 \%)$. Although organic standards allow artificial insemination, in all goat farms breeding is natural or direct. Breeding is seasonal, and females and males remain together continually, thereby avoiding the use of synthetic hormones. These practices, along with the use of breeds adapted to the region, contribute to the high level of compliance with organic standards for this indicator.

\subsubsection{Animal Welfare}

For this indicator, the goat farms of the six municipalities showed intermediate to very high (between 64.5 and 93.5\%) levels of compliance with organic standards (Table 3). On the one hand, they rate high with respect to: (I) kids not weaned until 45 days of age, (II) sufficient space per animal in roofed facilities and outdoors ( $\mathrm{G}=100 \% ; \mathrm{A}=78.0 \%$; $\mathrm{SP}=100 \% ; \mathrm{C}=100 \% ; \mathrm{T}=100 \% ; \mathrm{P}=93.0 \%$ ), and (III) zero to moderate availability of feeders and troughs $(\mathrm{G}=30 \% ; \mathrm{A}=0.0 \% ; \mathrm{SP}=35.0 \% ; \mathrm{C}=20.0 \% ; \mathrm{T}=37.0 \% ; \mathrm{P}=90.0 \%)$. Meanwhile, 
(IV) protection from weather conditions (cold, heat, rain and humidity) ranges from low to high $(\mathrm{G}=30.0 \% ; \mathrm{A}=50.0 \%$; $\mathrm{SP}=65.0 \% ; \mathrm{C}=45.0 \%$; $\mathrm{T}=47.0 \% ; \mathrm{P}=85.0 \%)$. And $(\mathrm{V})$ few farmers cut or trim horns of animals of any age $(<9 \%)$. Goat farmers are recommended to improve animal welfare by providing optimal conditions for their goats to reproduce, produce milk, and in general satisfy their biological needs [95].

\subsubsection{Food Safety}

The goat farms of all six municipalities have a zero approximation to the organic model $(0.0 \%$; Table 3$)$ with respect to food safety. Disease diagnosis and vaccination campaigns carried out by the National Service of Health, Safety, and Agrifood Quality (SENASICA according to its Spanish initials) are set out principally to detect brucellosis in animals over four months of age and have detected seropositive animals. Each year in the study region all herds are sampled and, upon detecting seropositive animals, SENASICA recommends sacrificing them or disinfecting installations with any of the products specified by organic standards, principally formaldehyde or caustic soda. Some goat farmers do not comply with these recommendations, which poses a sanitary threat for the entire herd as well as for herds that graze nearby. Additional blood samples are taken three and ten months after the initial sample, and if seropositive animals are not found, the herd is determined to be brucellosis-free. Another illness present in the region is tuberculosis, which is frequent in cattle, but no campaign exists to detect this disease in goats.

None of the goat farms of the six municipalities carry out strict hygienic-sanitary control of installations and equipment, and their goat meat has not been demonstrated to be free of chemical substances such as antibiotics, hormones, and pesticides. Nevertheless, due to the fact that the goats feed according to organic livestock production standards, artificial hormones are not used in reproduction, and chemical fertilizers, herbicides, and pesticides are not used in rangelands and grasslands. It is unlikely that the meat is contaminated with pesticides or other chemical substances prohibited by organic standards. Evidence of food safety of animal products, in this case meat, is the guarantee of quality that the farmer provides the consumer. Non-compliance with this indicator hinders the fulfillment of organic standards in the six municipalities evaluated. In order to overcome this, it is necessary to implement strict hygienic-sanitary control of infrastructure and equipment and demonstrate that goat products are free of substances prohibited by organic standards.

Food safety, together with organoleptic qualities (flavor, odor, and color of the meat) and nutritional qualities, constitute the sanitary and nutritional quality of food and contribute to consumer confidence. In recent years, consumers have increasingly considered meat from grazed livestock to be more natural and less contaminated than conventionally raised livestock, and to indicate respect for animal welfare [96,97]. Thus, increasing food safety not only improves animal welfare but also provides an opportunity for goat farmers to access niche markets.

\subsubsection{Ecological Management}

For this indicator, the goat farms of all six municipalities have a low or zero approximation to organic standards (Table 3) because government officials have not promoted policies oriented to improving the five variables that determine ecological management: (I) advisory and/or training for certification, (II) having an organic development or certification plan, (III) internal control of the organic process, (IV) receiving incentives for organic goat farming, and (V) a fair and/or constant sale price of products throughout the year. It is necessary to implement procedures that allow goat farmers to obtain advisory and training for transitioning toward organic farming. Goat farms require internal control of production, processing, and marketing according to organic standards [98]. The government is recommended to protect goat farmers from price fluctuations and provide incentives for high-quality production (e.g., goat raising with low use of external inputs, using silvopastoral systems) to stimulate these farmers to improve their farms by using sustainable management techniques [24,75,95]. 


\subsection{Goat production in the Lower Mixteca Region of Puebla and Sustainability}

\subsubsection{Social Sustainability}

Goat farmers of the six study municipalities are predominantly adults under age 50, with the exception of those of Guadalupe and San Pedro $(p<0.01$; Table 4$)$. Younger goat farmers have shown greater openness to receiving advisory and training and are more interested in implementing technological innovations, which provide an opportunity for developing sustainable goat raising systems such as organic goat farming, which-aside from providing crucial agroecosystems services- provides products of animal origin which are competitive with conventional products according to their quality. This coincides with the observed tendency that the younger the farmer, the greater the net margin per hectare per year. Similarly, greater openness to innovation by young adult cattle farmers has been reported by Nahed et al. [99] in the community of Tierra Nueva in the "El Ocote" Biosphere Reserve in Chiapas.

The goat farms of Piaxtla are managed by farmers who have been raising goats for less time $(p<0.01)$ than those of San Pedro, and a tendency was observed that the longer they have raised goats, the greater the net margin per hectare per year. Goats have been raised in the region for over four centuries, since the Spanish conquistadors (1536 to 1620; Miranda [100]) introduced the species to the lower Mixteca region in order to obtain pelts and lard [101,102].

Goat farmers of Acatlán and San Pedro have a very high (100\%) expectation of intergenerational continuity of goat raising, unlike $(p<0.01)$ those of the other municipalities (60 to $80 \%$ ). The majority of goat farmers have not finished primary school or are illiterate, which limits implementation improvements on their farms. Acatlán and San Pedro tend to have their goat farms on private land $(p<0.01)$, while communal (Ejido) land tenancy predominating $(p<0.01)$ in Tehuitzingo, Chinantla, and Guadalupe. Landholdings of $\mathrm{Pi}$ axtla are divided between private and communal property (approximately 50\% of each).

\subsubsection{Environmental Sustainability}

Despite the fact that the number of goats (16.9-30.9) in the goat farms and herd size standardized in animal units (4.3-8.7) vary $(p>0.05)$ among the six municipalities (Table 4$)$, goat diet is predominantly based on grazing in all municipalities. In the region, principally three types of grazing land exist: (I) rangelands with secondary vegetation, (II) rangelands with scattered shrubs and trees, and (III) open induced grasslands with few woody plants.

In all municipalities, rangeland with scattered shrubs and trees is the most abundant type of grazing surface area, with Chinantla having the greatest $(p<0.05)$ surface area of this type of rangeland. Rangeland with secondary vegetation rates second in abundance ( 0 to 0.8 ha per municipality) and is present in all municipalities except for Tehuitzingo and Guadalupe. Goats from Chinantla and Tehuitzingo also graze in small areas (C = 0.4 ha and $\mathrm{T}=0.1 \mathrm{ha}$ ) of open induced grassland with few woody plants. The surface area of grazing land owned by the goat farmers, obtained from the sum of the three types of grazing land described above, is less in Acatlán than in the other municipalities, while farmers of Chinantla have the greatest average owned grazing land $(p<0.05)$.

Goat herds of Guadalupe, San Pedro, and Piaxtla graze on small surface areas of rented rangeland as well as rangeland owned by the farmers. In all evaluated municipalities, goats also consume harvest residues directly in crop fields. The surface area of land with harvest residues is greatest $(p<0.05)$ in the goat farms of Guadalupe and lowest in the goat farms of San Pedro. The total surface area for grazing (including owned grazing land, rented grazing land, and surface area of harvest waste) was statistically greatest $(p<0.05)$ in Guadalupe, and lowest in San Pedro. 
Table 4. Average values ( \pm standard error) of the variables that characterize goat farms sustainability of six municipalities of the lower Mixteca region of Puebla, Mexico.

\begin{tabular}{|c|c|c|c|c|c|c|c|}
\hline & \multicolumn{6}{|c|}{ Municipalities } & \multirow[b]{3}{*}{ F; $p$ Value } \\
\hline & Guadalupe & Acatlán & San Pedro & Chinantla & Tehuitzingo & Piaxtla & \\
\hline Variables & (G) $n=20$ & (A) $n=20$ & (SP) $n=20$ & (C) $n=20$ & (T) $n=19$ & (P) $n=20$ & \\
\hline \multicolumn{8}{|l|}{ Social } \\
\hline Farmer age, years & $60^{\mathrm{a}} \pm 3.0$ & $48^{\mathrm{ab}} \pm 3.3$ & $55^{\mathrm{a}} \pm 2.4$ & $45.6^{\mathrm{b}} \pm 3.7$ & $45.5^{b} \pm 2.8$ & $48.5^{\mathrm{ab}} \pm 2.8$ & $3.9 ; 0.01$ \\
\hline Time raising goats, years & $29.3^{\mathrm{ab}} \pm 3.8$ & $21.4^{\mathrm{ab}} \pm 2.7$ & $29.6^{\mathrm{a}} \pm 2.5$ & $20.9^{\mathrm{ab}} \pm 1.8$ & $21^{\mathrm{ab}} \pm 2.2$ & $16.4^{\mathrm{b}} \pm 2.4$ & $3.6 ; 0.01$ \\
\hline Intergenerational continuity, \% & $80^{\mathrm{ab}} \pm 9.2$ & $100^{\mathrm{a}} \pm 0$ & $100^{\mathrm{a}} \pm 0$ & $60^{\mathrm{b}} \pm 11.2$ & $84.2^{\mathrm{ab}} \pm 8.6$ & $75^{\mathrm{ab}} \pm 9.9$ & $3.7 ; 0.01$ \\
\hline Farmer's formal education, years * & $2.7 \pm 0.7$ & $3.5 \pm 0.5$ & $4.5 \pm 0.8$ & $4.2 \pm 0.6$ & $5.5 \pm 0.7$ & $4.6 \pm 0.7$ & $2.0 ; 0.082$ \\
\hline Private land tenancy, $\%$ & $40.0^{\mathrm{bc}} \pm 11.2$ & $100^{\mathrm{a}} \pm 0$ & $65.0^{\mathrm{ab}} \pm 10.9$ & $25.0^{c} \pm 9.9$ & $31.6^{\mathrm{bc}} \pm 10.9$ & $50.0^{\mathrm{bc}} \pm 11.5$ & $7.6 ; 0.001$ \\
\hline \multicolumn{8}{|l|}{ Environmental } \\
\hline Goats present, heads ${ }^{1} *$ & $21.5 \pm 3.2$ & $16.9 \pm 5.5$ & $22.9 \pm 3.4$ & $25.2 \pm 2.4$ & $20.6 \pm 1.5$ & $30.9 \pm 3.1$ & $1.9 ; 0.097$ \\
\hline Herd size, $\mathrm{AU}$ & $5.6^{\mathrm{ab}} \pm 0.7$ & $4.3^{\mathrm{ab}} \pm 1.2$ & $6.5^{\mathrm{ab}} \pm 0.9$ & $8.0^{\mathrm{a}} \pm 0.7$ & $6.3^{\mathrm{ab}} \pm 0.4$ & $8.7^{\mathrm{a}} \pm 0.7$ & $2.2 ; 0.05$ \\
\hline Open induced grassland, ha * & $0.0 \pm 0.0$ & $0.0 \pm 0.0$ & $0.0 \pm 0-0$ & $0.4 \pm 0.5$ & $0.1 \pm 0.13$ & $0.0 \pm 0$ & $1.2 ; 0.3$ \\
\hline Rangelands with secondary vegetation, ha & $0.0^{\mathrm{b}} \pm 0.0$ & $0.05^{\mathrm{b}} \pm 0.05$ & $0.8^{\mathrm{a}} \pm 0.4$ & $0.2^{\mathrm{ab}} \pm 0.1$ & $0.0^{\mathrm{b}} \pm 0.0$ & $0.1^{\mathrm{ab}} \pm 0.2$ & $2.9 ; 0.05$ \\
\hline Rangelands with scattered shrubs and trees, ha & $12.3^{\mathrm{ab}} \pm 1.9$ & $7.7^{\mathrm{ab}} \pm 0.9$ & $7.1^{\mathrm{b}} \pm 1.7$ & $14.0^{\mathrm{a}} \pm 1.7$ & $13.2^{\mathrm{ab}} \pm 2.1$ & $13.9^{\mathrm{ab}} \pm 2.4$ & $3.0 ; 0.05$ \\
\hline Own rangeland, ha & $12.3^{\mathrm{ab}} \pm 1.9$ & $7.8^{b} \pm 0.9$ & $7.9^{\mathrm{ab}} \pm 1.6$ & $14.6^{\mathrm{a}} \pm 1.8$ & $13.3^{\mathrm{ab}} \pm 2.1$ & $14.0^{\mathrm{ab}} \pm 2.4$ & $2.9 ; 0.05$ \\
\hline Rented rangeland, ha * & $0.4 \pm 0.3$ & $0.0 \pm 0.0$ & $0.3 \pm 0.3$ & $0.0 \pm 0$ & $0.0 \pm 0$ & $0.3 \pm 0.4$ & $1.3 ; 0.268$ \\
\hline Stover areas, ha & $4.7^{\mathrm{a}} \pm 1.0$ & $2.5^{\mathrm{ab}} \pm 0.2$ & $1.7^{\mathrm{b}} \pm 0.5$ & $1.8^{\mathrm{ab}} \pm 0.3$ & $2.5^{\mathrm{ab}} \pm 0.2$ & $1.8^{\mathrm{ab}} \pm 0.3$ & $2.4 ; 0.05$ \\
\hline Grazing Total area, ha & $17.4^{\mathrm{a}} \pm 2.8$ & $10.3^{\mathrm{ab}} \pm 1.0$ & $9.9^{b} \pm 1.9$ & $16.4^{\mathrm{ab}} \pm 1.8$ & $15.8^{\mathrm{ab}} \pm 2.1$ & $16.1^{\mathrm{ab}} \pm 2.4$ & $2.9 ; 0.05$ \\
\hline Rangelands with proper grazing management, $\%$ & $95.0^{\mathrm{ab}} \pm 5.0$ & $100^{\mathrm{a}} \pm 0$ & $95.0^{\mathrm{ab}} \pm 5.0$ & $60.0^{\mathrm{c}} \pm 11.2$ & $63.2^{\mathrm{bc}} \pm 11.4$ & $60.0^{c} \pm 11.2$ & $5.4 ; 0.001$ \\
\hline \multicolumn{8}{|l|}{ Economic } \\
\hline Young animals sold per goat per year, heads & $0.37^{\mathrm{abc}} \pm 0.06$ & $0.30^{\mathrm{bc}} \pm 0.05$ & $0.27^{c} \pm 0.02$ & $0.52^{\mathrm{a}} \pm 0.05$ & $0.52^{\mathrm{ab}} \pm 0.06$ & $0.43^{\mathrm{abc}} \pm 0.11$ & $6.6 ; 0.001$ \\
\hline $\begin{array}{c}\text { Gross income from goat raising per ha of grazing } \\
\text { land per year, MX\$ }\end{array}$ & $1022^{b} \pm 145$ & $1106^{\mathrm{ab}} \pm 123$ & $1939^{a} \pm 302$ & $1731^{\mathrm{ab}} \pm 363$ & $1232^{\mathrm{ab}} \pm 150$ & $1334^{\mathrm{ab}} \pm 184$ & $2.8 ; 0.05$ \\
\hline Production cost per ha of grazing per year, $\mathrm{MX} \$$ * & $150 \pm 43$ & $258 \pm 35$ & $328 \pm 82$ & $169 \pm 30$ & $235 \pm 45$ & $362 \pm 97$ & $1.8 ; 0.113$ \\
\hline Net margin per ha of grazing land per year, MX\$ & $872^{b} \pm 157$ & $848^{b} \pm 110$ & $1611^{\mathrm{a}} \pm 234$ & $1562^{\mathrm{ab}} \pm 337$ & $997^{\mathrm{ab}} \pm 131$ & $972^{a b} \pm 142$ & $3.3 ; 0.01$ \\
\hline Contribution of goat raising to annual income, $\%$ & $22.9^{b} \pm 3.1$ & $19.6^{c} \pm 3$ & $28.1^{\mathrm{abc}} \pm 3.3$ & $41.5^{\mathrm{ab}} \pm 5.5$ & $31.8^{\mathrm{abc}} \pm 4.7$ & $43.5^{\mathrm{a}} \pm 4.6$ & $5.4 ; 0.001$ \\
\hline \multirow{2}{*}{$\begin{array}{c}\text { Contribution of sown crops to annual income, } \% \\
\text { Contribution of non-agricultural income to } \\
\text { annual income, } \%\end{array}$} & $20.8^{a} \pm 1.8$ & $14.5^{\mathrm{ab}} \pm 1.6$ & $18.5^{\mathrm{ab}} \pm 4.4$ & $9.5^{\mathrm{b}} \pm 1.8$ & $15.0^{\mathrm{ab}} \pm 3$ & $24.4^{\mathrm{a}} \pm 3.0$ & $5.4 ; 0.001$ \\
\hline & $56.3^{\mathrm{a}} \pm 4.1$ & $64.9^{\mathrm{a}} \pm 3.4$ & $52.4^{\mathrm{a}} \pm 4.6$ & $46.9^{\mathrm{ab}} \pm 5.9$ & $50.3^{\mathrm{ab}} \pm 7.2$ & $26.2^{b} \pm 6.1$ & $6.3 ; 0.001$ \\
\hline
\end{tabular}

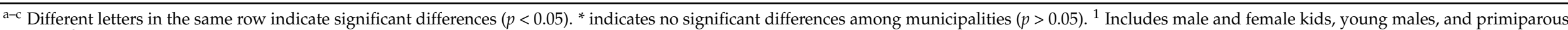
females. ${ }^{2}$ Ejido: communal landholding. 
The rotation strategy of rangelands leads that the stocking rate of this land to generally low, ranging from $0.32 \mathrm{AU} / \mathrm{ha}$ in Guadalupe to $0.66 \mathrm{AU} /$ ha in San Pedro. Finally, the greater the stocking rate, the greater the net margin per ha per year. For this reason, grazing and conservation are well-managed in the rangelands, as observed in the values of the variable rangelands with proper grazing management, which vary $(p<0.001)$ from $60 \%$ in Chinantla to $100 \%$ in Acatlán (Table 4). This is also observed in the tendency that the greater the value of the indicators of feed management, sustainable rangeland management, organic soil fertilization, disease prevention, veterinary care, animal welfare, and ecological management, the greater the sustainability of the goat farms.

\subsubsection{Economic Sustainability}

The number of young animals (including male and female kids, young males, and primiparous females) sold annually per goat ranges from 0.27 in San Pedro to 0.52 in Chinantla and Tehuitzingo $(p<0.001)$. Gross income (in Mexican pesos) from goat raising per ha of grazing land per year is greatest $(p<0.05)$ in San Pedro and lowest in Guadalupe. A tendency toward a greater cost of production per ha of grazing land per year is observed in Piaxtla and San Pedro, although differences among municipalities are not significant. However, the net margin per ha of grazing land per year was significantly greatest $(p<0.01)$ in San Pedro, due to its high stocking rate and high gross income from goat raising per ha of grazing land per year (Table 4).

With respect to total family income, in all goat farms of all six municipalities, goat raising contributes more to annual income than does sow crops. The percentage of annual income from the goat farms which comes from sown crops is greatest $(p<0.001)$ in Piaxtla and lowest in Chinantla. Meanwhile, the percentage of non-agricultural income to the annual income of the goat farms is greater $(p<0.001)$ in Acatlán and San Pedro than in Piaxtla. With the exception of Piaxtla, where income from goat raising is greater than non-agricultural income, non-agricultural activities contribute much more to the annual income of the goat farms than do goat raising and crop agriculture (Table 4).

\subsection{Holistic Analysis of Goat Production in the Mixteca Region of Puebla: Compliance with Organic Standards and Sustainability}

The objective of organic agriculture is to create integrated production systems which are environmentally and economically sustainable. Organic farming should address social justice and social rights, which promote sustainability $[103,104]$. The level of sustainability of an organic farm is one of the principal factors in determining the level of acceptability of its practices [105].

Several aspects of goat farms of the Mixteca region of Puebla contribute to their potential for conversion to organic farming, as seven of the ten indicators evaluated (58\% of the final OLCI value) had moderate to very high levels of compliance with organic standards, indicating that they have potential for sustainability. Despite the fact that the OLCI values of the goat farms in the municipalities of the study region are moderate to very high (Table 3), a direct relationship was observed between the values of this index and those of sustainability. Thus, the greater the OLCI value, the greater the sustainability of the goat farms $\left(r^{2}=0.97\right)$. Therefore, compliance of goat farms in the Mixteca region of Puebla with organic standards contributes to their sustainability. Evidence that organic farming improves sustainability has been reported by many authors [28-30,106-109]. For example, Toro-Mujica et al. [109] report that organic dairy sheep farms in Castille-La Mancha, Spain have greater levels of sustainability than do conventional semi-intensive sheep farms.

Organic agriculture maintains the health of soils, ecosystems, and people based on ecological processes, biodiversity, and agricultural management adapted to local conditions, while avoiding inputs with adverse effects [104]. More than actively carrying out practices to promote sustainability, goat production in the Mixteca region of Puebla does not involve practices prohibited by organic standards. So that goat raising in this region may improve sustainability, goat farms should implement practices such as conservation and improvement of pastures and other landscapes; restoration of marginal lands; integra- 
tion of livestock and crops; conservation and/or enhancing of biodiversity; use of botanical insecticides, repellants, and integrated pest management; prevention and reduction of parasites and other diseases through natural methods such as homeopathy and herbalism; control of internal parasites through grazing management; and use of fodders containing beneficial secondary compounds. Furthermore, animal products should be shown to be safe and free of chemical substances such as antibiotics, anabolics, and other hormones.

The majority of the indicators used to evaluate the level of compliance of goat production in the Mixteca region of Puebla with organic standards were related to the social and environmental aspects of sustainability. Participatory innovation processes on goat farms for sustainable development of silvopastoral systems and organic goat farming allows for safe, healthy, ecologically-responsible food production and mitigation of-and adaptation to-climate change. It also provides a variety of benefits that are lacking in conventional agricultural systems, such as production of meat, milk, natural fertilizer, construction materials, and firewood, as well as environmental services that benefit people on a local, regional-landscape, and global level $[16,110]$.

While this evaluation of approximation of goat raising to the organic model included few variables of the economic and social dimensions of sustainability. The findings with respect to some of the social and economic structural variables (for example gross income from goat raising per ha of grazing land per year, cost of production per ha of grazing land per year, the contribution of goat raising to annual income, and intergenerational continuity) indicate that goat production in the lower Mixteca region of Puebla may improve both dimensions of sustainability.

With respect to the economic dimension of sustainability, results for gross income from goat raising per ha of grazing land per year and production cost per ha of grazing land per year, indicate that goat raising is profitable, contributing more to annual income than crop agriculture. Although the contribution of goat production to annual income in the lower Mixteca region of Puebla is modest, similar to that of other grazing systems, agricultural practices compatible with organic standards improve net margin, similar to that found for organic sheep farms of Castille-La Mancha, Spain [111] and organic cattle farms in Tuscany, Italy, which show greater gross margin than conventional farms [108]. According to Pacini et al. [106], organic cattle farms in Tuscany have a greater gross margin than conventional cattle farms principally due to the fact that the increase in income, due to a combination of higher prices for organic products, subsidies for organic agriculture, and elimination of costs of chemical fertilizers and pesticides, was greater than the reduction in profits, that stems from lower yields in organic farms. In the same region, Moriondo et al. [112] report that on conventional cattle farms, a lesser gross margin is associated with greater leaching of nitrogen, while with organic cattle farms lesser gross margin is associated with less nitrogen leaching.

In the Mixteca region of Puebla, high values for the variables intergenerational continuity and family labor may significantly contribute to the social sustainability of goat raising. According to Ripoll-Bosch et al. [113], in the Mediterranean, dairy sheep herds have been reduced due to lack of generational turnover. This is similar to the case of sheep herds from Andalusia [114] and low-input grazed sheep and cattle raising in the European Mediterranean watershed [33]. Generational turnover is particularly important to sustainability, as found on sheep farms of the European Mediterranean watershed, where high rates of generational turnover were fundamental to sustainability on a farm level [113]. Family labor, which is crucial for profitability, favors social sustainability, as demonstrated for small-scale dairy cattle production in the highlands of central Mexico [115] and dualpurpose cattle farms with moderate global sustainability in the subtropical region of central Mexico, where family labor contributes to social well-being. Family participation on farms contributes to assuring generational turnover [116]. Similarly, the availability of low-cost family labor greatly contributes to the profitability of small-scale ruminant producers, particularly for milk production [117]. 
In rural territories, extensive livestock management not only contributes to the conservation of natural and cultural patrimony, including nature, landscapes, and biodiversity [118], but also directly contributes to social and economic sustainability, demographic stability, and high local quality of life.

In order to determine the contributions of goat raising to economic and social sustainability, it is necessary to increase research of both dimensions of sustainability, particularly with respect to (I) the contribution of goat farming to food security and sustainability [104,111,119-121], (II) the quality of goat products [106], (III) rural employment [121,122], (IV) safe dignified working conditions [106], (V) social equity with respect to-for example-gender, race, ethnicity, and class, (VI) quality of life for agricultural families and communities [104,113,123], (VII) family labor and generational turnover, and (VII) goat farmers' perceptions regarding the sustainability of their farms [113].

Conservation of scrublands, wild fauna, and biodiversity through grazing; seed dispersal; and prevention of forest fires are examples of agroecosystem services of the goat farms studied that may be improved in order to contribute to their sustainability.

Publicizing the characteristics of the meat of animals raised in extensive grazing systems such as those evaluated could promote its consumption locally and regionally [124]. Furthermore, products from livestock grazing systems may easily be certified with respect to the denomination of origin and incorporated into agroecological markets, as consumer demand for such products is increasing. This would justify local and national government support for agroecological markets and provide farmers with effective distribution mechanisms [118], which would reinforce the social and economic sustainability of livestock farms that involve grazing, such as those evaluated in the present study. Consumers increasingly consider free-range meat products to be healthy, not contaminated, and produced with respect for animal welfare and without negative environmental impact $[96,97]$. Due to consumer demand for such products, interest in extensive livestock production is increasing, which provides an opportunity for sustainable development of livestock grazing systems [125].

The quality of animal products is closely related to their sustainability and environmental impact, as recognized by many authors $[28,126,127]$. Grazing goats and sheep results in meat with organoleptic characteristics which are more beneficial to human health than those of animals raised in confinement [125,128-131], and it is generally accepted that the diversity of grasses and other plants consumed by grazing animals increases the quality of the meat [124,132-134]. Furthermore, the presence of secondary compounds in some plants consumed by grazing animals-including phenolic compounds such as condensed tannins, saponins, and essential oils rich in terpenes [135]-also potentially increases product quality. Tannins may alter ruminal microorganisms, modifying the profile of fatty acids that leave the rumen and potentially positively influencing the content of beneficial fatty acids in milk and meat-such as linolenic, vaccenic, and rumenic acids [136], aside from promoting the stability of the color of fresh meat [137].

Direct distribution channels (local markets), fair trade, and labeling of original brandswhich are frequently linked to organic farming-may also contribute to economic and social sustainability.

Labeling of organic products which state nutritional, organoleptic, and environmental advantages, due to the animals grazing, may increase consumer confidence and their willingness to pay a fair price for such products, thereby generating benefits for the farmers. Other aspects that may be mentioned in the labeling of organic products are their artisanal nature and the fact that their consumption helps to perpetuate traditions, culture in general, and dietary culture in particular. Furthermore, labeling and publicity may mention aspects related to social solidarity (for example social solidarity, or collaborative economies), emphasizing the importance of supporting farmers who contribute to the production of healthy foods, mitigation of climate change, and development of poor marginal communities. 
Farmer organizations are fundamental to improving the sustainability of goat farms. For example, upon organizing cooperatives, extensive sheep farms in Spain were able to participate in training, improve their infrastructure, add value to their products, access markets, and achieve price stability, thereby contributing to the persistence of their farms [138]. Fomenting organic livestock raising, which requires fosters fair trade and better communication and coordination among social actors (farmers, researchers and policymakers) to develop local, state, and national agricultural policies, also improves the income from goat raising.

\section{Conclusions}

For goat farmers of the arid and semi-arid lower Mixteca region of Puebla, extensive grazing allows for taking advantage of fodder resources of rangelands in order to obtain meat for self-provisioning and sale of surplus products. In this region, pastoral, silvopastoral, and agrosilvopastoral management of Creole goats which are highly adapted to local climatic conditions is carried out in extensive communal grazing land. The management calendar is adapted to the variability of environmental conditions. Goat farms of the lower Mixteca region use little external inputs; carry out little economic reinvestment, and have a low level of installations, equipment, technological development, and marketing channels. Furthermore, few farmers belong to farmer organizations.

Values for the Organic Livestock Conversion Index of the goat farms in the six studied municipalities (48.0-53.6\%) indicated a moderate level of compliance with organic standards. These goat farms are recommended to improve their levels of the following indicators: sustainable rangeland management- (with the exception of goat farms of Piaxtla, which rate high in this indicator) as there is a given insufficient rotation of grazing land, little cultivation of woody fodder crops, and failure to improve natural grasses, organic soil fertilization as that goat farmers do not apply organic fertilizers to grazing land, disease prevention and veterinary care due to the low level of immunization of animals against diseases and insufficient quarantining of introduced and sick animals, and food safety and ecological management. Those indicators showing a high level of compliance with the organic standards are feed management, weed control in rangelands and grasslands, pest and disease control in rangelands and grasslands, breeds and reproduction, and animal welfare.

In order to increase the levels of the indicators for areas in which the goat farms of the study area have a low level of compliance with the organic model and a low level of sustainability, it is necessary for greater involvement of farmers, researchers, and technical advisors in developing local, state, and national agricultural policies that increase farmer capacity to improve their farms. The greater openness of younger farmers to receiving advisory and training and their greater interest in implementing innovations as compared to older adults provide opportunities for sustainable development of organic goat production.

In the goat farms of the study region, a younger age, a longer time raising goats, a higher formal education level of farmers, and a greater stocking rate favored a greater net margin per ha of grazing land per year.

Greater sustainability was indicated by greater values of the indicators feed management, sustainable rangeland management, organic soil fertilization, disease prevention and veterinary care, animal welfare, and ecological management. Furthermore, those goat farms in which goat raising contributed a greater percentage to annual income had a higher net margin per hectare of pasture per year, which in turn is associated with greater sustainability. Finally, we observed that the greater the value of the Organic Livestock Conversion Index in the goat farms, the greater their sustainability.

Author Contributions: Conceptualization, J.N.T.; Z.G.L.T.; J.R.A.J.; D.G.C.; and C.D.P.; methodology, J.N.T.; Z.G.L.T.; J.R.A.J.; D.G.C.; and C.D.P.; software, J.N.T.; Z.G.L.T.; J.R.A.J.; D.G.C.; and C.D.P.; validation, J.N.T.; Z.G.L.T.; J.R.A.J.; D.G.C.; and C.D.P.; formal analysis, J.N.T.; Z.G.L.T.; J.R.A.J.; D.G.C.; and C.D.P.; investigation, J.N.T.; Z.G.L.T.; J.R.A.J.; D.G.C.; and C.D.P.; resources, J.N.T.; 
Z.G.L.T.; J.R.A.J.; D.G.C.; and C.D.P.; data curation, J.N.T.; Z.G.L.T.; J.R.A.J.; D.G.C.; and C.D.P.; writing—original draft preparation, J.N.T.; Z.G.L.T.; J.R.A.J.; D.G.C.; and C.D.P.; writing-review and editing, J.N.T.; Z.G.L.T.; J.R.A.J.; D.G.C.; and C.D.P.; visualization, J.N.T.; Z.G.L.T.; J.R.A.J.; D.G.C.; and C.D.P.; supervision, J.N.T.; Z.G.L.T.; J.R.A.J.; D.G.C.; and C.D.P.; project administration, J.N.T.; and Z.G.L.T.; funding acquisition, J.N.T.; and Z.G.L.T. All authors have read and agreed to the published version of the manuscript.

Funding: This research was funded by El Colegio de la Frontera Sur and el Colegio de Postgraduados (México). The APC was funded by Colegio de Postgraduados.

Data Availability Statement: The data presented in this study are available on request from the corresponding author.

Acknowledgments: We thank Ann Greenberg for her support in translating and reviewing the manuscript; and to the goat farmers of the lower Mixteca region of Puebla, Mexico, for their support during fieldwork.

Conflicts of Interest: The authors declare no conflict of interest. The funders had no role in the design of the study; in the collection, analyses, or interpretation of data; in the writing of the manuscript, or in the decision to publish the results.

\section{References}

1. Ritchie, H.; Roser, M. Land Use. Published Online at Our World in Data. 2020. Available online: https://ourworldindata.org/ land-use (accessed on 15 February 2021).

2. Klein Goldewijk, K.; Beusen, A.; Doelman, J.; Stehfest, E. Anthropogenic land use estimates for the Holocene-HYDE 3.2. Earth Syst. Sci. Data 2017, 9, 927-953. [CrossRef]

3. Our World in Data. The World Has Lost One-Third of Its Forests, But an End of Deforestation is Possible. Available online: https: / / ourworldindata.org/deforestation\#the-world-has-lost-one-third-of-its-forests-but-an-end-of-deforestation-is-possible (accessed on 15 February 2021).

4. FAO. FAOSTAT. Available online: http://www.fao.org/faostat/en/\#home (accessed on 7 November 2019).

5. Íñiguez, L. The challenges of research and development of small ruminant production in dry areas. Small Rumin. Res. 2013, 98, 12-20. [CrossRef]

6. SIAP. Sistema de Información Agroalimentaria y Pesquera. SAGARPA. Población Ganadera Caprina 2010-2019. Available online: https://www.gob.mx/cms/uploads/attachment/file/564339/Inventario_2019_caprino.pdf (accessed on 20 June 2020).

7. Boza, J. Papel del ganado caprino en las zonas desfavorecidas. Pequeños Rumiantes 2006, 7, 30-38.

8. Contreras, C.M.; Auhad, L.; Renolfi, R.; Ruiz, S.; Martinez, M.; Piedrasanta, R.; Orella, P.; Lazarte, M.; Pisano, P. Serie de Informes Técnicos Estación Experimental Agropecuaria Santiago del Estero. Caracteristicas del manejo de la majada caprina en el suroeste Santiagueño, 1th ed.; INTA: San Miguel de Tucuman, Argentina, 2016; Volume 92, p. 24.

9. Squires, V.R. People in rangelands: Their role and influence on rangeland utilization and sustainable management. In Range and Animal Sciences and Resources Management; Squires, V., Ed.; Encyclopedia of Life Support Systems; EOLSS/UNESCO, EOLSS Publishers: Oxford, UK, 2010; pp. 36-59.

10. Rota, A.; Sperandini, S. Livestock and Pastoralists. Livestock Thematic Papers: Tools for Project Design; International Fund for Agricultural Development: Rome, Italy, 2009; Available online: http:/ /www.ifad.org/lrkm/factsheet/pastoralists. (accessed on 10 April 2021).

11. Espinoza-Villavicencio, J.L.; Palacios-Espinosa, A.; Ávila -Serrano, N.; Guillén-Trujillo, A.; de Luna-de la Peña, R.; Ortega-Pérez, R.; Murillo-Amador, B. La ganadería orgánica, una alternativa de desarrollo pecuario para algunas regiones de México: Una revisión. Interciencia 2007, 32, 385-390.

12. IFOAM. International Federation of Organic Agriculture Movements. The Four Principles of Organic Agriculture. The Principles of Organic Agriculture Are Health, Ecology, Fairness and Care. Available online: http://www.ifoam.org/about_ifoam/ principles/index.html (accessed on 13 January 2011).

13. Pimentel, D.; Hepperly, P.; Hanson, J.; Douds, D.; Seidel, R. Environmental, energetic, and economic comparisons of organic and conventional farming systems. BioScience 2005, 55, 573-582. [CrossRef]

14. Calle, A.; Soler, M.; Rivera, M.G. Food sovereignty and Emerging Agroecology: Dietary democracy. In Approximations to Radical Democracy: Between Connections and Utopias; Calle, A., Ed.; ICARIA: Barcelona, Spain, 2011; pp. 213-238.

15. Gerber, P.J.; Steinfeld, H.; Henderson, B.; Mottet, A.; Opio, C.; Dijkman, J.; Falcucci, A.; Tempio, G. Confronting Climate Change through Livestock Production-A Global Evaluation of Emissions and Opportunities for Mitigation; Food and Agriculture Organization of the United Nations (FAO): Rome, Italy, 2013.

16. Nahed-Toral, J.; Sanchez-Muñoz, B.; Mena, Y.; Ruiz-Rojas, J.; Aguilar-Jimenez, R.; Castel, J.; De Asis-Ruiz, F.; Orantes-Zebadua, M.; Manzur-Cruz, A.; Cruz-Lopez, J.; et al. Feasibility of converting agrosilvopastoral systems of dairy cattle to the organic production model in southeastern Mexico. J. Clean. Prod. 2013, 43, 136-145. [CrossRef] 
17. Sarandón, J.S. El desarrollo y uso de indicadores para evaluar la sustentabilidad de los agroecosistemas. In Agroecología, el Camino Hacia una Agricultura Sustentable; Ediciones Científicas Americanas: Buenos Aires, Argentina, 2002; pp. $394-414$.

18. Mena, Y.; Nahed, J.; Ruiz, F.A.; Sánchez-Muñoz, J.B.; Ruiz-Rojas, J.L.; Castel, J.M. Evaluating mountain goat dairy systems for conversion to the organic model, using a multicriteria method. Animal 2012, 6, 693-703. [CrossRef]

19. Nahed, J.; Grande, D.; Aguilar, J.R.; Sánchez, B. Possibilities for converting conventional cattle production to the organic model in the Grijalva River Basin, Mexico. Cogent Food Agric. 2016, 2, 1153767. [CrossRef]

20. Kaufmann, R.K.; Cleveland, C.J. Measuring sustainability: Needed-an interdisciplinary approach to an interdisciplinary concept. Ecol. Econ. 1995, 15, 109-112. [CrossRef]

21. Belcher, K.W.; Boehm, M.M.; Fulton, M.E. Agroecosystems sustainability: A system simulation model approach. Agric. Syst. 2004, 79, 291-316. [CrossRef]

22. Byström, S.; Jonsson, S.; Martinsson, K. Organic versus conventional dairy farming studies from the Öjebyn Project. In Proceedings of the UK Organic Research 2002 Conference; Powell, J., Ed.; Organic Centre Wales, Institute of Rural Studies, University of Wales Aberystwyth: Wales, UK, 2002; pp. 179-184.

23. Olivares, P.R.; Gómez, C.M.A.; Meraz, A.M. Potential for conversion of conventional livestock farms to organic production systems in the State of Tabasco. Rev. Mex. Cienc. Pecu. 2005, 43, 361-370.

24. Nahed, J.; Castel, J.M.; Mena, Y.; Caravaca, F. Appraisal of the sustainability of dairy goat systems in Southern Spain according to their degree of intensification. Livest. Sci. 2006, 101, 10-23. [CrossRef]

25. Nahed, J.; García Barrios, L.; Mena, Y.; Castel, J.M. Uso de indicadores para evaluar la sustentabilidad de los sistemas agrosilvopastoriles. In Agroforestería Pecuaria en Chiapas, México; Jiménez, G., Nahed, J., Soto, L., Eds.; ECOSUR: San Cristóbal de las Casas, Chiapas, México, 2007; pp. 54-60.

26. Masera, O.; Astier, M.; López-Ridaura, S. Sustentabilidad y Manejo de Recursos Naturales. El Marco de Evaluación MESMIS, 1st ed.; Editorial Mundi-Prensa: Mexico City, Mexico, 1999; pp. 5-88.

27. Bagenal, S. Barriers and Opportunities for the Development of the Organic Milk Market. Proceedings Organic Food and Farming, The Danish Ministry of Food. 2001. Available online: www.fvm.dk (accessed on 15 September 2018).

28. Ronchi, B.; Nardone, A. Contribution of organic farming to increase sustainability of Mediterranean small ruminants livestock systems. Livest. Prod. Sci. 2003, 80, 17-31. [CrossRef]

29. Cruz, J.F.; Prieto, C. Approach to the assessment of sustainability in organic livestock farms in a Colombian Andean region. In Proceedings of the 4th ISOFAR Scientific Conference, at the Organic World Congress, Istanbul, Turkey, 13-15 October 2014; Rahmann, G., Aksoy, U., Eds.; Building Organic Bridges: Braunschweing, Germany, 2014; pp. 159-162.

30. Nahed, T.J.; González-Pineda, S.; Grande, D.; Aguilar, R.; Sánchez, B.; Ruiz, J.; Guevara- Hernández, F.; León, N.; Trujillo-Vázquez, R.; Parra-Vázquez, M. Evaluating sustainability of conventional and organic dairy cattle production units in the Zoque Region of Chiapas, Mexico. Agroecol. Sustain. Food. 2019, 43, 605-638. [CrossRef]

31. Ruiz, F.; Mena, Y.; Sayadi, S.; Castel, J.M.; Navarro, L.; Nahed, J. Social indicators for evaluating sustainability of goat livestock farms: Methodological approach. Trop. Subtrop. Agroecosystems 2009, 11, 65-68.

32. Peacock, C.; Sherman, D.M. Sustainable goat production-Some global perspectives. Small Rumin. Res. 2010, 89, 70-80. [CrossRef]

33. Bernués, A.; Ruiz, R.; Olaizola, A.; Villalba, D.; Casasús, I. Sustainability of pasture-based livestock farming systems in the European Mediterranean context: Synergies and trade-offs. Livest. Sci. 2011, 139, 44-57. [CrossRef]

34. FAO. Sustainable goat breeding and goat farming in Central and Eastern European countries. In Proceedings of the European Regional Conference on Goats, Rome, Italy, 7-13 April 2014; Kukovics, S., Ed.; Food and Agriculture Organization of the United Nations: Rome, Italy, 2016; p. 281.

35. Caroprese, M.; Albenzio, M.; Sevi, A. Sustainability of Sheep and Goat Production Systems. In The Sustainability of Agro-Food and Natural Resource Systems in the Mediterranean Basin; Vastola, A., Ed.; Springer International Publishing AG: Cham, Switzerland, 2015; pp. 65-75.

36. Paraskevopoulou, C.; Theodoridis, A.; Johnson, M.; Ragkos, A.; Arguile, L.; Smith, L.; Vlachos, D.; Arsenos, G. Sustainability Assessment of Goat and Sheep Farms: A Comparison between European Countries. Sustainability 2020, 12, 3099. [CrossRef]

37. FND. Financiera Nacional de Desarrollo Agropecuario, Rural, Forestal y Pesquero. Información del Sector Rural en área pecuario, México. 2014. Available online: http:/ /www.financierarural.gob.mx/informacionsectorrural/Panoramas/Panorama\% 20Bovino\%20(may\%202014).pdf (accessed on 20 April 2021).

38. Ramírez, A. CSR (corporate social responsibility) and the triple account of results. Financ. Strat. 2006, $231,56-62$.

39. Valentin, A.; Spangenberg, J.H. A guide to community sustainability indicator. Environ. Impact Assess Rev. 2000, 20, 381-392. [CrossRef]

40. Organización de las Naciones Unidas (ONU). Asamblea General. Informe de Secretario General. Avances logrados hasta el momento y lagunas que aún persisten en la aplicación de los resultados de las principales cumbres en la esfera del desarrollo sostenible y análisis de los temas de la Conferencia. Tema 3 del Programa Provisional. Comité Preparatorio de la Conferencia de las Naciones Unidas sobre el Desarrollo Sostenible. 17-19 mayo, 2010. p. 33. Available online: https:/ /www.cepal.org/sites/ default/files/events/files/rio-avances_y_lagunas_04.2010.esp_.pdf (accessed on 10 May 2021).

41. Bercovics, D. Fiche de lecture. In Cannibals with Forks: The Triple Bottom Line of 21st Century Business; Majeure Alternative Management-HEC: Paris, France, 2010; pp. 1-16. 
42. Hernández, J.E.; Franco, F.J.; Villarreal, O.A.; Camacho, J.C.; Pedraza, R.M. Caracterización socioeconómica y productiva de unidades caprinas familiares en la Mixteca Poblana. Arch. Zootec. 2011, 60, 175-182. [CrossRef]

43. SNIM. Fichas Básicas Municipales. Estado de Puebla. Sistema Nacional de Información Municipal. Instituto para el Federalismo y el Desarrollo Municipal, Puebla, México. 2021. Available online: http://www.snim.rami.gob.mx/ (accessed on 25 April 2021).

44. INEGI. Prontuario de información geográfica municipal de los Estados Unidos Mexicanos. Puebla. Instituto Nacional de Estadística, Geografía e Informática. 2009. Available online: https:/ / docplayer.es/39455058-Prontuario-de-informacion-geograficamunicipal-de-los-estados-unidos-mexicanos-puebla-puebla-clave-geoestadistica-21114.html (accessed on 3 February 2021).

45. INEGI. Anuario estadístico de Puebla 2009. Instituto Nacional de Estadística y Geografía, Gobierno del Estado de Puebla. México. 2009. Available online: http://internet.contenidos.inegi.org.mx/contenidos/productos/prod_serv/contenidos/ espanol/bvinegi/productos/historicos/2104/702825200886-1/702825200886-1_1.pdf (accessed on 14 April 2021).

46. INAFED. Enciclopedia de los Municipios y Delegaciones de México, Estado de Puebla. Available online: http://www.inafed.gob. $\mathrm{mx}$ /work/enciclopedia/EMM21puebla/index.html (accessed on 16 October 2016).

47. INEGI. VIII Censo Agrícola, Ganadero y Forestal 2007. Instituto Nacional de Estadística, Geografía e Informática. 2007. Available online: https:/ /www.inegi.org.mx/rnm/index.php/catalog/219/related_materials?idPro=(accessed on 14 April 2021).

48. Méndez, R.I.D.; Namira, G.L.; Moreno., A.; Sosa de, M.C.; Cañedo, D.L.; Shabot, A.E. Protocolo de Investigación, Lineamientos Para su Elaboración; Editorial Trillas: Mexico City, México, 1986; p. 332.

49. Vela, F. Un acto metodológico básico de la investigación social: La entrevista cualitativa. In María Luisa Tarrés (coord.) Observar, Escuchar y Comprender: Sobre la Tradición Cualitativa en la Investigación Social; Tarrés, M.L., Ed.; Porrúa and FLACSO: Mexico City, Mexico, 2001; pp. 63-95.

50. Gillham, B. Research Interviewing: The Range of Techniques; McGraw Hill Education: Berkshire, UK, 2005.

51. López, T.Z.G.; Ocampo, F.I.; Parra, I.F. Participación social en la construcción de cisternas de ferrocemento para la captación y almacenamiento de agua de lluvia en la Mixteca poblana. In Agua y Desarrollo local Ante el Cambio Climático; Villarreal, M.L.A., Ocampo, F.I., Hernández, R.M.L., Eds.; Altres Costa-Amic: Puebla, México, 2014; pp. 114-130.

52. Hernández, S.J.H.; Tornero, C.M.A.; Sandoval, C.E.; López, T.Z.G.; Calderón, S.F.; Villarreal, M.L.A. Microrregión Mixteca Poblana: Innovación y transferencia de tecnología en el cultivo de sorgo (Sorghum vulgare L). In El Enfoque Regional en el Desarrollo Agrícola. La Innovación en Agricultura Campesina, Colegio de Postgraduados-Campus Puebla; Ocampo, F.I., Ramirez, J.J., Eds.; Altres Costa-Amics: Puebla, México, 2016; p. 24, Altres Costa-Amics: Puebla, México, 2016.

53. Delgadillo, P.C.; Cuchillo, H.M.; Navarro, O.A.; Medina-Campos, O.; Nieto, C.A.; Ramírez, A.T.; López-Tecpoyotl, Z.G.; Díaz, M.M.; Álvarez-Izazaga, M.A.; Cruz, M.Y.R.; et al. Phenolic Compounds in Organic and Aqueous Extracts from Acacia farnesiana Pods Analyzed by ULPS-ESI-Q-oa/TOF-MS. In Vitro Antioxidant Activity and Anti-Inflammatory Response in CD-1 Mice. Molecules 2018, 23, 2386.

54. Delgadillo-Puga, C.; Cuchillo-Hilario, M.; León-Ortiz, L.; Ramírez-Rodríguez, A.; Cabiddu, A.; Navarro-Ocaña, A.; MoralesRomero, A.M.; Medina-Campos, O.N.; Pedraza-Chaverri, J. Goats' Feeding Supplementation with Acacia farnesiana Pods and Their Relationship with Milk Composition: Fatty Acids, Polyphenols, and Antioxidant Activity. Animals 2019, 9, 515. [CrossRef] [PubMed]

55. Hernández-García, E.; García, A.; Avalos-Alanís, F.G.; Rivas-Galindo, V.; Delgadillo-Puga, C.; Camacho-Corona, M.R. Nuclear magnetic resonance spectroscopy data of isolated compounds from Acacia farnesiana (L) Willd fruits and two esterified derivatives. Data Brief 2018, 22, 255-268. [CrossRef]

56. Falconi, F.; Burbano, R. Economic tools for environmental management: Mono-criteria vs. multi-criteria decisions. Revibec 2004, 1, 11-20.

57. Munda, G. Multicriteria methods and multicriteria processes for social evaluation of public policy. Revibec 2004, 1, 31-45.

58. Munda, G.; Nijkamp, P.; Rietveld, P. Fuzzy multigroup conflict resolution for environmental management. In The Economics of Project Appraisal and the Environment; Weiss, J., Ed.; Edward Elgar: Aldershot, UK, 1994; pp. 161-183.

59. Guzmán, C.G.; Alonso, M.A. Design of the transition process to ecological agriculture. In The Practice of Agriculture and Ecological Livestock Raising; Andalusian Committee of Ecological Agriculture: Seville, Spain, 2001; pp. 341-348.

60. Grimm, J.W.; Wozniak, P.R. Basic Social Statistics and Quantitative Research Methods; Western Kentucky University, Wadsworth Publishing Co: Belmont, CA, USA, 1990.

61. Toussaint, G. Notice of indicators for functioning of dairy systems. Options Mediterr. 2002, 39, 147-157.

62. Mena, Y.; Castel, J.M.; Toussaint, G.; Caravaca, F.; Gonzalez, P.; Sanchez, S. FAO CIHEAM dairy system indicators of adaptation to semi-extensive dairy goat systems. In Proceedings of the 8th International Conference on Goats, Pretoria, South Africa, 4-9 July 2004.

63. Nahed, T.J.; López, T.G. Avances de investigación. In Evaluación de la Sostenibilidad y Aproximación de la Caprinocultura Convencional de la Mixteca Baja Poblana. Informe de Estancia Sabática; ECOSUR/Colegio de Postgraduados: Cholula, Puebla México, $2018 ;$ p. 46.

64. Zar, J. Biostatistical Analysis, 2nd ed.; Prentice-Hall: Hoboken, New Jersey, USA, 1984; p. 718.

65. SPSS. Statistical Package for Social Sciences Users Manual Base 15.0; SPSS Inc.: Chicago, IL, USA, 2006.

66. Gomez-Quiles, J.M.; Gutierrez-Romulo, A.; Preciado-de la Torre, J.F.; Martinez-Rojas, L.R. Goat production system in the Mixteca Poblana Region. Vet. Mex. 1995, 26, 421.

67. Hernández, Z.J.S. La caprinocultura en el marco de la ganadería poblana (México): Contribución de la especie caprina y sistemas de producción. Arch. Zootec. 2000, 49, 341-352. 
68. Hernández, J.S.; Rodero, E.; Herrera, M.; Delgado, J.V.; Barba, C.; Sierra, A. La caprinocultura en la mixteca poblana (México). Descripción e identificación de factores limitantes. Arch. Zootec. 2001, 50, 231-239.

69. Castel, J.M.; Mena, Y.; Delgado-Pertíñez, M.; Camúñez, J.; Basulto, J.; Caravaca, F.; Guzmán-Guerrero, J.L.; Alcalde, M.J. Characterization of semi-extensive goat production systems in southern Spain. Small Rumin. Res. 2003, 47, 133-143. [CrossRef]

70. Koyuncu, M.; Uzun, Ş.K.; Tuncel, E. Characterization of Semi-Extensive Goat Production Systems in South Marmara Region of Turkey. J. Biol. Environ. Sci. 2008, 2, 53-58.

71. Valdivieso Pérez, I.A.; Nahed Toral, J.; Piñeiro Vázquez, A.T.; Guevara Hernández, F.; Jiménez Ferrer, G.; Grande Cano, D. Potential for organic conversion and energy efficiency of conventional livestock production in a humid tropical region of Mexico. J. Clean. Prod. 2019, 241, 118354. [CrossRef]

72. Rodríguez-Moreno, O.G.; Nahed-Toral, J.; Guevara-Hernández, F.; Alayón-Gamboa, J.A.; Grande-Cano, J.D. Historia y caracterización técnica y socioeconómica de la ganadería bovina en la costa de Chiapas, México. Trop. Subtrop. Agroecosystems 2020, 23, $1-13$.

73. Mena, Y.; Nahed, J.; Ruiz, F.A.; Castel, J.M.; Ligero, M. Proximity to the organic model of dairy goat systems in the Andalusian Mountains (Spain). Trop. Subtrop. Agroecosystems 2009, 11, 69-73.

74. Aguilar-Jiménez, J.R.; Nahed-Toral, J.; Parra-Vázquez, M.R.; Guevara-Hernández, F.; Pat-Fernández, L.A. Adaptability of Cattle-Raising to Multiple Stressors in the Dry Tropics of Chiapas, Mexico. Sustainability 2019, 11, 1955. [CrossRef]

75. Nahed, J.; Calderón, J.; Aguilar, R.; Sánchez, B.; Ruiz, J.; Mena, Y.; Castel, J.; Ruiz, F.; Jiménez, G.; López, J.; et al. Approximation of agrosilvopastoral systems of three micro-regions of Chiapas, Mexico to the organic production model. Av. Investig. Agropecu. $2009,13,45-58$.

76. Escribano, A.J. Beef cattle farms' conversion to the organic system: Recommendations for success in the face of future changes in a global context. Sustainability 2016, 8, 572. [CrossRef]

77. Cuchillo, M.; Puga, D.C.; Wrage, N.; Espinosa, M.J.G.; Montaño, R.F.; Navarro-Ocaña, A.; Ledesma, J.A.; Díaz, M.M.; Pérez-Gil, R.F. Nutritional value, antioxidant activity and bioactive compounds of vegetation species ingested by goats on semiarid rangelands. J. Anim. Feed Sci. 2013, 22, 106-115. [CrossRef]

78. Abrego, H.R. El sistema de Producción y Clasificación Fenotípica de las Cabras de la Mixteca Poblana. Master’s Thesis, Colegio de Postgraduados, Campus Puebla, Mexico, 2013.

79. IFOAM. International Federation of Organic Agriculture Movements. In The IFOAM Norms for Organic Production and Processing; IFOAM-Organics International: Bonn, Germany, 2005.

80. Regulations, Council Regulation (EC) No. 834. On organic production and labelling of organic products and repealing (EEC) No 2092/9. Off. J. European Union 2007, L 189/1, 1-23.

81. Müller-Lindenlauf, M.; Deittert, C.; Köpke, U. Assessment of environmental effects, animal welfare and milk quality among organic dairy farms. Livest. Sci. 2010, 128, 140-148. [CrossRef]

82. Calderón, S.F.; Mera, Z.F.; Ayala, B.F.; Guerrero, R.J.D.; López, T.Z.G.; Ortiz, R.G.A. Composición química y digestibilidad in vitro de la materia seca de especies arbóreas y arbustivas consumidas por los caprinos en la mixteca poblana. In Fortalecimiento de la Innovación Tecnológica y Competitividad de la Cadena de Valor Caprina en el Estado de Puebla (FOMIX 77110); CONACYT-Gobierno del Estado de Puebla: Puebla, México, 2011; p. 32.

83. Camacho, J.C.; Juárez, C.E.; Franco, F.J.; Hernández, J.H. Composición bromatológica de plantas arbóreo-arbustivas consumidas en una época del año por cabras en la Mixteca Poblana, México. Arch. Latinoam. Prod. Anim. 2013, 21, $29-35$.

84. Hernández, J.; Carreón, L.; Villarreal, O.A.; García, F.; Camacho, J.C. Elaboration and costs multi-nutritional blocs with goatee leaves (Pithecellobium acatlense) consumed by goats in the Mixteca Poblana, Mexico. J. Agric. Sci. 2014, 5, 165-169. [CrossRef]

85. López, O.J.C.; Morales, O.O.; Ramírez, B.E.; Soriano, R.R.; Arias, M.L.; Almaraz, B.I. Plantas forrajeras de la Mixteca Oaxaqueña consumidas por ganado caprino en pastoreo. In XVIII Congreso Internacional de Ovinocultura; Congreso Nacional Caprino: Puebla, México, 2014; pp. 67-71.

86. Delgadillo, P.C.; Cuchillo, H.M.; Espinosa, M.J.G.; Medina, C.O.; Molina, J.E.; Díaz, M.M.; Álvarez, I.M.A.; Ledesma, S.J.A.; Pedraza-Chaverri, J. Antioxidant activity and protection against oxidative-induced damage of Acacia shaffneri and Acacia farnesiana pods extracts: In vitro and in vivo assays. BMC Complement. Altern. Med. 2015, 15, 1-8. [CrossRef] [PubMed]

87. Sánchez, E.; Heredia, N.; Camacho, C.M.R.; García, S. Isolation, characterization and mode of antimicrobial action against Vibrio cholerae of methyl gallate isolated from Acacia farnesiana. J. Appl. Microbiol. 2013, 115, 1307-1316. [CrossRef] [PubMed]

88. Hernández-García, E.; García, A.; Garza-González, E.; Avalos-Alanís, F.G.; Rivas-Galindo, V.M.; Rodríguez-Rodríguez, J.; Alcantar-Rosales, V.M.; Delgadillo-Puga, C.; Del Rayo Camacho-Corona, M. Chemical composition of Acacia farnesiana (L) wild fruits and its activity against Mycobacterium tuberculosis and dysentery bacteria. J. Ethnopharmacol 2019, 230, 74-80. [CrossRef]

89. Lague, C.; Landry, H.; Roberge, M. Engineering of land application systems for livestock manure: A review. Can. Biosyst. Eng. 2005, 47, 17-28.

90. Labrador, J.; Porcuna, J.L. Aproximación a las bases técnicas de la agricultura ecológica. In Conocimientos, Técnicas y Productos 922 para la Agricultura y la Ganadería Ecológica, 2nd ed.; Labrador, J., Ed.; Sociedad Española de Agricultura Ecológica: Madrid, Spain, 2006; pp. 19-34.

91. Nogueroles, C.; Sicilia, A. Descomposición y aprovechamiento de la materia orgánica. In Conocimientos, Técnicas y Productos Para 925 la Agricultura y la Ganadería Ecológica, 2nd ed.; Labrador, J., Ed.; Sociedad Española de Agricultura Ecológica: Madrid, Spain, 2006; pp. 49-61. 
92. Menalled, F.D.; Gross, K.L.; Hammond, M. Weed aboveground and seed bank community responses to agricultural management systems. Ecol. Appl. 2001, 11, 1586-1601. [CrossRef]

93. Isman, M.B. Botanical insecticides, deterrents, and repellents in modern agriculture and an increasingly regulated world. Annu. Rev. Entomol. 2006, 51, 45-66. [CrossRef]

94. Cook, S.M.; Khan, Z.R.; Pickett, J.A. The use of push-pull strategies in integrated pest management. Annu. Rev. Entomol. 2007, 52, 375-400. [CrossRef]

95. von Borell, E.; Sørensen, J.T. Organic livestock production in Europe: Aims, rules and trends with special emphasis on animal health and welfare. Livest. Prod. Sci. 2004, 90,3-9. [CrossRef]

96. Hersleth, M.; Naes, T.; Rødbotten, M.; Lind, V.; Monteleone, E. Lamb meat-Importance of origin and grazing system for Italian and Norwegian consumers. Meat Sci. 2012, 90, 899-907. [CrossRef]

97. Vasta, V.; Pagano, R.I.; Luciano, G.; Scerra, M.; Caparra, P.; Foti, F.; Cilione, C.; Biondi, L.; Priolo, A.; Avondo, M. Effect of morning vs. afternoon grazing on intramuscular fatty acid composition in lamb. Meat Sci. 2012, 90, 93-98. [CrossRef]

98. CERTIMEX. Normas Para la Producción, el Procesamiento y la Comercialización de Productos Ecológicos; Certificadora Mexicana de Productos y Procesos Ecológicos S.C: Oaxaca, Mexico, 2007.

99. Nahed, T.J.; Gomez, H.; Pinto, R.; Guevara, F.; Medina, F.; Ibrahim, M.; Grande, D. Research and development of silvopatoral systems in a village in the Buffer Zone of the El Ocote Biosphere Reserve, Chiapas, Mexico. Res. J. Biol Sci. $2010,5,499-507$.

100. Miranda, J. Las Mercedes de Tierras en el Siglo XVI. Historia Mexicana. 1954. Available online: www.jstor.org/stable/25134338 (accessed on 8 May 2020).

101. García, H.L.A. La Caprinocultura en la Mixteca Oxaqueña. Orígenes. 1996. Available online: http://www.ejournal.unam.mx/ cns/no44/CNS04405.pdf (accessed on 5 November 2020).

102. Mendoza, G.E. El Ganado Comunal en la Mixteca Alta: De La época colonial al Siglo XII. El Caso De Tepelmeme. Historia Mexicana 2002, 51, 749-785.

103. Pathak, P.K.; Chander, M.; Biswas, A.K. Organic Meat: An Overview. Asian-Aust. J. Anim. Sci. 2003, 16, $1230-1237$.

104. IFOAM. International Federation of Organic Agriculture Movements. In The IFOAM Norms for Organic Production and Processing; IFOAM-Organics International: Bonn, Germany, 2014; p. 128.

105. Lampkin, N.; Measures, M. Organic Farm Management Handbook: Organic Farming Research Unit; Institute of Rural Studies, University of Wales: Aberystwyth, Wales, UK, 2001.

106. Pacini, C.; Wossink, A.; Giesen, G.; Vazzana, C.; Huirne, R. Evaluation of sustainability of organic, integrated and conventional farming systems: A farm and field-scale analysis. Agric. Ecosyst. Environ. 2003, 95, 273-288. [CrossRef]

107. Chander, M.; Mukherjee, R. Organic animal husbandry: Concept, status and possibilities in India-A review. Indian J. Anim. Sci. 2005, 75, 1460-1469.

108. Sandhu, H.S.; Wratten, S.D.; Cullen, R. The role of supporting ecosystem services in conventional and organic arable farmland. Ecol. Complex. 2010, 7, 302-310. [CrossRef]

109. Toro-Mujica, P.; García, A.; Perea, J.; de Pablos-Heredero, C.; Barba, C.; Angón, E. A sustainability assessment of organic dairy sheep systems in Castille La Mancha (Spain). Rev. Científica FCV-LUZ 2014, 24, 553-562.

110. Nahed-Toral, J.; Valdivieso-Pérez, A.; Aguilar-Jiménez, R.; Cámara-Cordova, J.; Grande-Cano, D. Silvopastoral systems with traditional management in southeastern Mexico: A prototype of livestock agroforestry for cleaner production. J. Clean. Prod. 2013, 57, 266-279. [CrossRef]

111. Badgley, C.; Moghtader, J.; Quintero, E.; Zakem, E.; Chappell, M.J.; Vazquez, K.A.; Samulon, A.; Perfecto, I. Organic agriculture and the global food supply. Renew. Agric. Food Syst. 2007, 22, 86-108. [CrossRef]

112. Moriondo, M.; Pacini, C.; Trombi, G.; Vazzana, C.; Bindi, M. Sustainability of dairy farming system in Tuscany in a changing climate. Eur. J. Agron. 2010, 32, 80-90. [CrossRef]

113. Ripoll-Bosch, R.; Díez-Unquera, B.; Ruiz, R.; Villalba, D.; Molina, E.; Joy, M.; Olaizola, A.; Bernués, A. An integrated sustainability assessment of Mediterranean sheep farms with different degrees of intensification. Agric. Syst. 2012, 105, 46-56. [CrossRef]

114. Ruíz, F.A.; Castel, J.M.; Mena, Y. Labour characterization of Andalusian goat farms. Future perspectives. In Economic, Social and Environmental Sustainability in Sheep and Goat Production Systems; Bernués, A., Boutonnet, J.P., Casasús, I., Chentouf, M., Gabiña, D., Joy, M., López-Francos, A., Morand-Fehr, P., Pacheco, F., Eds.; CIHEAM/FAO/CITADGA: Zaragoza, Spain, 2011 ; pp. 349-359.

115. Posadas-Domínguez, R.R.; Arriaga-Jordán, C.M.; Martínez-Castañeda, F.E. Contribution of family labour to the profitability and competitiveness of small-scale dairy production systems in central Mexico. Trop. Anim. Health. Prod. 2014, 46, 235-240. [CrossRef]

116. Salas-Reyes, I.G.; Arriaga-Jordán, C.M.; Rebollar-Rebollar, S.; García-Martínez, A.; Albarrán-Portillo, B. Assessment of the sustainability of dual-purpose farms by the IDEA method in the subtropical area of central Mexico. Trop. Anim. Health. Prod. 2015, 47, 1187-1194. [CrossRef]

117. McDermott, J.J.; Staal, S.J.; Freeman, H.A.; Herrero, M.; Van de Steeg, J.A. Sustaining intensification of smallholder livestock systems in the tropics. Livest. Sci. 2010, 130, 95-109. [CrossRef]

118. SECF. Sociedad Española de Ciencias Forestales. Consideraciones y conclusiones finales. El papel de la ganadería extensiva en la silvicultura preventiva y la gestión del medio natural. IV Reunión de Trabajo del Grupo de Sistemas Agroforestales. Estación Experimental del Zaidín, Consejo Superior de Investigaciones Científicas. Granada, Spain. Octubre 19-21, 2011. Available online: http:/ / www.pastoresmonte.org/Reuni\%C3\%B3n+GT+Sistemas+Agroforestales+2011 (accessed on 10 April 2021). 
119. Krystallis, A.; Chryssohoidis, G. Consumers' willingness to pay for organic food: Factors that affect it and variation per organic product type. Br. Food J. 2005, 107, 320-343. [CrossRef]

120. El-Hage Scialabba, N. Organic agriculture and food security. Conference Presentation. In Proceedings of the International Conference on Organic Agriculture and Food Security, Rome, Italy, 3-5 May 2007; FAO: Rome, Italy; p. 22.

121. Nemes, N. Comparative Analysis of Organic and Non-Organic Farming Systems: A Critical Assessment of Farm Profitability; FAO: Rome, Italy, 2009; p. 33.

122. Prihtanti, T.M.; Hardyastuti, S.; Hartono Irham, S. Social-cultural functions of rice farming systems. Asian J. Agric. Rural Dev. 2014, 4, 341-351.

123. Reganold, J.P.; Wachter, J.M. Organic agriculture in the twenty-first century. Nat. Plants 2016, 2, 15221. [CrossRef]

124. Ådnøy, T.; Haug, A.; Sørheim, O.; Thomassen, M.S.; Varszegi, Z.; Eik, L.O. Grazing on mountain pastures-does it affect meat quality in lambs? Livest. Prod. Sci. 2005, 94, 25-31. [CrossRef]

125. De Brito, G.F.; Ponnampalam, E.N.; Hopkins, D.L. The effect of extensive feeding systems on growth rate, carcass traits, and meat quality of finishing lambs. Compr. Rev. Food Sci. Food Saf. 2017, 16, 23-38. [CrossRef]

126. Arnould, V.M.R.; Reding, R.; Bormann, J.; Gengler, N.; Soyeurt, H. Review: Milk composition as management tool of sustainability. Biotechnol. Agron. Soc. Environ. 2013, 17, 613-621.

127. Muchenje, V.; Mukumbo, F.E.; Njisane, Y.Z. Meat in a sustainable food system. S. Afr. J. Anim. Sci. 2018, 48, 818-828. [CrossRef]

128. Priolo, A.; Micol, D.; Agabriel, J. Effects of grass feeding systems on ruminant meat colour and flavour. A review. Anim. Res. EDP Sci. 2001, 50, 185-200. [CrossRef]

129. Zurita-Herrera, P.; Delgado-Bermejo, J.V.; Argüello-Henríquez, A.; Camacho-Vallejo, M.E.; Germano-Costa, R. Effects of three management systems on meat quality of dairy breed goat kids. J. Appl. Anim. Res. 2013, 41, 173-182. [CrossRef]

130. Goetsch, A.L.; Merkel, R.C.; Gipson, T.A. Factors affecting goat meat production and quality. Small Rumin. Res. 2011, 101, 173-181. [CrossRef]

131. Gutiérrez-Peña, R.; Delgado-Pertíñez, M.; Guzmán-Guerrero, J.L.; Horacada, A. Perfil de ácidos grasos de la carne de cordero de raza autóctona Mallorquina en función del peso y de la alimentación. In Proceedings of the Libro de Actas de la $56^{\mathrm{a}}$ Reunión Científica de la Sociedad Española para el Estudio de los Pastos, Barcelona, Spain, 25-28 April 2017; Filella, J.D., Albanell, E., Milán, M.J., Serrano, E., Broncano, M.J., Manuelian, C.L., Eds.; Sociedad Española para el Estudio de los Pastos: Barcelona, España, 2017; pp. 216-221.

132. Lourenço, M.; Van Ranst, G.; De Smet, S.; Raes, K.; Fievez, V. Effect of grazing pastures with different botanical composition by lambs on rumen fatty acid metabolism and fatty acid pattern of longissimus muscle and subcutaneous fat. Animal 2007, 1, 537-545. [CrossRef]

133. Lourenço, M.; Van Ranst, G.; Vlaeminck, B.; De Smet, S.; Fievez, V. Influence of different dietary forages on the fatty acid composition of rumen digesta as well as ruminant meat and milk. Anim. Feed. Sci. Technol. 2008, 145, 418-437. [CrossRef]

134. Willems, H.; Kreuzer, M.; Leiber, F. Alpha-linolenic and linoleic acid in meat and adipose tissue of grazing lambs differ among alpine pasture types with contrasting plant species and phenolic compound composition. Small Rumin. Res. 2014, 116, 153-164. [CrossRef]

135. Vasta, V.; Luciano, G. The effects of dietary consumption of plants secondary compounds on small ruminants' products quality. Small Rumin. Res. 2011, 101, 150-159. [CrossRef]

136. Morales, R.; Ungerfeld, E.M. Use of tannins to improve fatty acids profile of meat and milk quality in ruminants: A review. Chil. J. Agric. Res. 2015, 75, 239-248. [CrossRef]

137. Luciano, G.; Monahan, F.J.; Vasta, V.; Biondi, L.; Lanza, M.; Priolo, A. Dietary tannins improve lamb meat colour stability. Meat Sci. 2009, 81, 120-125. [CrossRef]

138. Gaspar, P.; Escribano, M.; Pulido, F.; Rodríguez-Ledesma, A.; Mesías, F.J.; Pulido, A.F. El papel de la gestión cooperativa en la mejora del funcionamiento técnico económico de explotaciones ovinas. Arch. Zootec. 2016, 65, 333-339. [CrossRef] 